\title{
Mai ve Siyah Romanının Göstergebilimsel Çözümlemesi*
}

\section{FUNDA UZDU YILDIZ**}

Öz

Göstergebilim anlamlı yapıları çözmeyi amaçlayan bir bilim dalıdır. Anlatılar da anlamlı yapılardan biridir. Bu çalışmada, Halit Ziya Uşaklıgil'in Mai ve Siyah adlı romanı göstergebilimin sunduğu yöntem ve araçlarla çözümlenmeye çalışılmıştır. Çözümleme süreci üç temel aşamada gerçekleştirilmiştir. İlk olarak betisel düzeyde betiler ve yerdeşlikler zaman, oyuncu ve uzam açısından incelenmiştir. İkinci aşama olan anlatısal düzeyde, Algirdas-Julien Greimas'ın “Eyleyenler Modeline” göre kahramanlar tanımlanmıştır. Ardından ise eyletim, edinç, edim ve yaptırım aşamaları ele alınmıştır.

Anahtar sözcükler: Göstergebilim, Anlatı Çözümleme, Kiplik, Eyleyen Şeması, Mai ve Siyah

\section{SEMIOTIC ANALYSIS OF THE NOVEL MAİ VE SIYAH}

Abstract

Semiotics is a branch of science which aims to analyze meaningful structures. Narratives are also one of these meaningful structures. In this study, Halit Ziya Uşakligil's novel Mai ve Siyah was tried to be analyzed with the methods and instruments presented by semiotics. The process of analysis was carried out in three basic stages. Firstly, in the figurative stage, the figures and isotopies were examined in terms of time, performer and space. Secondly, in the narrative stage, the protagonists were defined according to AlgirdasJulien Greimas'" The Actantial Model". Then the phases of manipulation, competence, performance and sanction were discussed.

Keywords: Semiotics, Narrative Analysis, Modality, Actant Schema, Mai ve Siyah

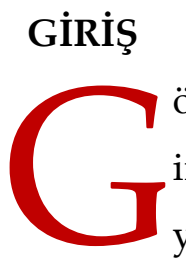

östergebilim çözümlemesinde temel amaç, anlamı ve anlam oluşumunu incelemek olduğundan incelediği nesnenin bütüncül ve tamamlanmış bir yapı olması beklenir. İncelenecek nesnenin bu bütünlük içinde alıcıya bir

\footnotetext{
* Bu çalışma, Ege Üniversitesi Sosyal Bilimler Enstitüsü Yeni Türk Edebiyatı Anabilim Dalında 2012 yılında Funda Uzdu Yıldız tarafından hazırlanan doktora tezinden üretilmiştir.

** Dokuz Eylül Ün. Edebiyat Fakültesi, Dilbilim Bölümü, fundauzdu@deu.edu.tr, orcid.org/0000-0003-1813-5432

Gönderim tarihi: 19-09-2019

Kabul tarihi: 19-11-2019
} 
anlam sunduğu düşünüldüğünde bu anlamın oluşum amaçları ve araçları göstergebilim aracılığılyla belirlenebilir. Bu belirleme her türlü inceleme nesnesi için ayrıntılı, yüzeyden derine inen bir okuma süreciyle gerçekleşebilir. Göstergebilim, nesnesinin birbirine benzeyen veya benzemeyen özelliklerini ortaya koyarak nesnesinin önceden oluşturulmuş yapısını betimledikten sonra, onu değişik bakış açılarıyla inceler, bakış açıları arasında bağıntılar kurar ve bunları belli bir dizge içinde sunar. Hiçbir bakış açısına öncelik ve ayrıcalık tanımaz (Kıran, 2004, s. 51). Kıran'ın belirttiği bu bilgilerden yola çıkarak ayrıntılı okuma sürecinde, göstergebilim çözümlemesinde sırayla şu aşamalarda çözümlemenin yapıldığı söylenebilir: İncelenen nesnedeki karşıtlıkların belirlenmesi; nesnenin yapısının ortaya çıkarılması, nesnenin değişik bakış açılarıyla incelenmesi ve öğeler arasında bağıntılar kurma ve bu bağıntıların belli bir dizge içinde sunulması. Yukarıda sıralanan çözümleme aşamalarının da gösterdiği gibi göstergebilim disiplinlerarası bir bilim dalı olarak hem betimlemeli hem de açıklamalı bir yapı sunar (Kıran, 2010, s. 2). Göstergebilim çözümleme aşamasında, incelediği anlamlı yapılardan biri üzerinde uygulamasını derinleştirerek özelden genele ulaşan bir anlamlama kuramına varmıştır. İnceleme alanı tüm göstergelerden oluşan göstergebilim, inceleme alanları içinden kendi içinde bütünlük gösteren belirli parçalar alıp bunlar üzerinde çalışma yoluna gitmiştir. Göstergebilimciler alt-evren kavramını getirerek araştırma alanını bölmüş, genel nitelikte bir anlamlama kuramı olarak gelişen genel göstergebilim uygulamaları niteliğinde birçok göstergebilim dalı oluşturmuşlardır (Yücel, 1991, s. 99). İnceleme nesnesi olarak yazın yapıtlarını ele alan yazınsal göstergebilim, genel göstergebilimin alt inceleme alanlarından biridir ve genel göstergebilim uygulamalarının da ilk olarak yapıldığı alandır. Genel göstergebilimin ilk ve ayrıntılı bir inceleme alanı olarak yazın yapıtlarını seçmesinin değişik nedenleri vardır. Greimas göstergebilimi, anlamlı bütünlere özgü anlamsal ayrılıkları, anlamsal eklemlenişi, anlamın üretilişini bir üstdil aracılığıyla yeniden üreterek yorumlamayı amaçlar (Rifat , 1998, s. 167). Yazın yapıtları da bireysel ve toplumsal söylemi belirleyen anlamlı bütünlerden biridir. Özellikle anlatılar, yani anlatılmasıyla anlamlı bir bütün oluşmasını sağlayan yapılar çözümlendiğinde anlam oluşumuna yönelik pek çok tutarlı bilgiye ulaşıldığı görülür. Yazınsal göstergebilim bütüncül ve tutarlı olmak için nesnesi kesinlikle belirlenmiş bir terimler bütünü ve örnekçeler kullanarak, bulgularını her zaman somut örneklere dayandırarak, hiçbir şeyi dışarıda bırakmadan, bütüncül bir biçimde betimleyip çözümlemeye yönelir. Yapıtı kendisi için ve kendi içindes kendi kendine yeterli bir yapı s bir anlam dizgesi olarak eşsüremlilik düzleminde ele alır. Yapıtı anlam açısından kuşatmak için onu hem bir kavram ulamları dizgesi ya da anlam evreni, hem de bir eylemler ve deneyimler kesiti ya da bir anlatı olarak çözümlemeye yönelir (Yücel, 2009, s. 94). Yazınsal göstergebilimin, alanında yapılan çalışmalarla anlatısal yapıların öteki yapıların önüne 
geçtiği ${ }_{s}$ bir bütünleyicilik bağlantısı içinde hepsini kendine bağladığı görülür. Anlatılar üzerinde yapılan çalışmalarda bütünü oluşturma ilkesi olarak görülen anlatısallık tüm anlamlı yapıların temel ilkelerinden biri haline gelir. Anlatısallık, halk masallarının ve yazınsal anlatıların yüzeysel örgüsü olmaktan çıkarak, sözsel ya da söz dışı, her türlü söylemin düzenleyici ilkesi olarak görülmeye ve bilisel ya da kılgısal değişik etkinlik türlerini eklemlemede ve yorumlamada vazgeçilmez bir araç niteliği kazanır (Yücel s 1991, s. 108). Bu aşamadan sonra yazınsal göstergebilim örneğinden yola çıarak tüm göstergebilim çözümlemelerinde anlatısallık, çözümlenmeye ve yapısını oluşturan öğeler açısından incelenmeye başlanmıştır. Yazınsal göstergebilimin temel konusu bir anlatıyı çözümlemek, anlamlandırmak ve anlatı olmasını sağlayan yönleri ortaya koymaktır (Günay, 2000, s. 39). Bunu yapabilmek için göstergebilimciler, göstergebilimden önce gelişen bazı çalışmaları incelemiş ve anlatı üzerine yapılan çalışmalarda derinleşmişlerdir. Yazınsal göstergebilim araştırmalarının birbirinden oldukça farklı iki ana çizgi üzerinde geliştiği söylenebilir: İçerik çözümlemesi ve anlatı işlevleri çözümlemesi (Yücel, 1982, s. 140). İçerik çözümlemesi yapıtın derin anlam oluşum aşamalarını belirleyip dizgesel olarak bunları tekrar düzenlemeye dayanır. Anlatı işlevleri çözümlemesi ise yazınsal anlatıların oluşumunu ortaya koymaya çalışır. Birinci çizgi olarak belirtilen içerik çözümlemesinde nesnel, sistemli ve genel özellikleri kapsayacak bir şekilde incelemeye gidilir. Yazın yapıtı katmanlı bir yapıya sahiptir. Her katman belirli öğelerden oluşur ve bu katmanlar arasında belirli bağlantılar söz konusudur. Anlatı öğeleri arasındaki bağlantıların ortaya çıkarılması gerekir. Bu bağlantılar, öğelerin, somut - soyut, karşıt - çelişik, bütünleyicilik ilkeleri içinde değerlendirilmeleriyle ortaya konur (Yücel, 2009, s. 95). Önce çözümlenen yazın yapıtı, bütünü yansıtacak genellemelerle anlamsal olarak bütünleştirilmiş olur.

Yazınsal göstergebilimde anlamın ortaya çıkışının üç özerk alanda gerçekleştiği düşünülür: belirim düzleminde yer alan ve anlamlama açısından doyurucu bir çözümleme alanı oluşturamayan metinsel yapılar yüzeysel göstergebilimsel yapıları içeren ve onları bir sözcelem sürecinden geçirerek söyleme aktarmayı üstlenen söylemsel yapılar ve anlamlamanın en derin, dolayısıyla en soyut düzeyini oluşturan göstergeselanlatısal yapılar (Yücel, 1991, s. 108).

“Genel izlem” olarak adlandırılan bu üç alan, özerk alanlar olmasına karşın anlam çözümlemesinde aralarında bağıntılar kurulabilir. Genel izlemin tamamı bir anlatıda anlamin oluşumunu göstermek için kullanılabileceği gibi bu izlemin bir bölümü de anlam oluşuma katkısı bakımından ele alınabilir. Kurmaca yapılar olan anlatıların incelendiği yazınsal göstergebilimde anlatı çözümlemesini betisel düzey, anlatısal düzey ve izleksel düzey gibi üç düzeyli bir inceleme biçiminde geliştirir ve bu çözümleme birimleri ile belli bir bütünlük ve kapalılık içinde sunulan anlatı incelenir, metni oluşturan birimler arasındaki ilişkiler ortaya konur (Günay s 2007, s. 190). Yücel'in belirttiği anlamın ortaya çıkış aşamaları 
ile benzerlik gösteren bu düzeylerde basitten karmaşı̆̆a, somuttan soyuta bir aşamalandırma söz konusudur.

Halit Ziya Uşaklıgil'in Mai ve Siyah romanı Türk edebiyatının karakter oluşturma bakımından önemli eserlerinden sayılır. Bir başkişi etrafında gelişen olaylarla birlikte, başkişinin ilişki içinde olduğu farklı karakterler de romanda ayrıntılı olarak görülebilmektedir. Romanın konusu kısa bir biçimde şöyle özetlenebilir: Roman, Ahmet Cemil karakteri çevresinde gelişir. Ahmet Cemil büyük bir şair, edebiyatçı olmayı hayal eden bir gençtir. Mülkiyede okumaktadır ve arkadaşı Hüseyin Nazmi ile birlikte şiirler okuyup şiir yazma denemeleri yapmaktadırlar. Günlük yaşantılarını şiirler üzerine düşünmekle, yeni kitapları takip etmekle geçirirler. Ancak Ahmet Cemil'in babası vefat edince Ahmet Cemil ailesini -kız kardeşini ve annesini- geçindirmek zorunda kalır. Kendisine küçük işler bulur, işten kalan zamanı yine şiirlere, okumaya, yazmaya ayırmak ister ama çok çalışmak zorunda olduğu için zaman sıkıntısı yaşar. Tercümanlık, öğretmenlik yapar ve Mir'ati Şuun gazetesinde matbaa işlerinde çalışır. Ahmet Cemil, yakın arkadaşı Hüseyin Nazmi'nin kız kardeşi Lamia'ya âşıktır ve onunla evlilik hayalleri kurar. Bir gün kitabını çıkarıp Lamia'yla evlenmek istemektedir. Ancak kurduğu hayaller gerçekleşmez, eserini bastıramaz. Kız kardeşinin eşi ile ortak kurdukları matbaa, eniştesinin borçlanması ve maddi sorunlar sebebiyle, aynı zamanda da Ahmet Cemil'in kız kardeşi İkbal'le eniştesinin geçimsizlikleri nedeniyle kapanır. Güzel, umut dolu hayallerle başlayan iş devam edemez. Eniştesi -Vehbi Bey- kötü bir eş olarak İkbal'e eziyet eder ve sonunda İkbal rahatsızlanır ve vefat eder. Bütün bu yaşananların arasında Lamia'ya açılamayan Ahmet Cemil'in aşkı da acıyla sonlanır. Lamia başkasıyla evlenir. En yakın arkadaşı Hüseyin Nazmi Avrupa'ya çalışmaya gider. İstediği gibi bir iş, bir hayat kuramayan, sevdiğine kavuşamayan, kardeşi vefat eden Ahmet Cemil sonunda ümitlerini yitirir. Tüm yaşadıklarını geride bırakmak istediği için uzak bir yere, Arabistan'a tayin ister ve atanır. Annesini yanına alarak İstanbul'dan çaresiz bir teslimiyet duygusuyla ayrilır.

$\mathrm{Bu}$ çalışmada birden çok anlatı kişisini örnekleyen bir eser olarak Mai ve Siyah seçilmiştir. Anlatı kişilerinin göstergebilimdeki kipliklere göre incelenebilmesi için Bertrand'ın belirttiği (2000, s. 29) anlamlamanın oluşum süreci aşamalarının ikinci bölümü olan anlatısal-göstergesel yapılar düzleminde yer alan anlatı şeması, eyleyenler ve kipsel yapılar belirlenmeye çalışılmıştır. Aşağıdaki tabloda da görülebileceği gibi anlatı kişilerinin incelenmesi bu aşamada olmaktadır. Anlatı kişilerinin eylemleri ya da kipsel durumları tek başına çözümlenemeyeceğinden anlatısal-göstergesel yapılar olabildiğince bir bütünlük içinde ele alınıp değerlendirilmiştir. Söylemsel yapılardan eyleyenlerin betimlemelerinde ve derin yapıdaki kiplikler için gerekli görülen aşamalarda göstergebilimsel dörtgenden yararlanılmıştır. 
Tablo 1: Anlamlamanın oluşum süreci

\begin{tabular}{cl}
\hline Söylemsel yapılar & $\begin{array}{l}\text { Betisel yerdeşlik (uzam, zaman, eyleyen) } \\
\text { İzleksel yerdeşlik }\end{array}$ \\
\hline Anlatısal-göstergesel & Anlatı şemasi (258eyletim - sözleşme-, edinç, edim \\
yapılar & -eylem-, yaptırım \\
& Eyleyensel sözdizim (özne, nesne, gönderen, karşı \\
& özne, anlatı izlencesi, anlatısal süreç) \\
& Kipsel yapılar (/istemek/,/zorunda olmak/, \\
& /bilmek/,/muktedir olmak/, /yapmak/ ya da \\
& /olmak/; bu kipliklerin olumsuzlukları) \\
& Temel anlam ve sözdizim (göstergebilimsel \\
& dörtgen: anlamlamanın temel yapısı) \\
\hline Derin yapılar & ve tutarlı olabilmesi için anlatı, kesitlere ay
\end{tabular}

İncelemenin daha ayrıntılı ve tutarlı olabilmesi için anlatı, kesitlere ayrılmıştır. Kesitlere ayırma genel bir bakışla temel durum ve dönüşümlere göre yapılmıştır. İnceleme, kesitler, kesitlerdeki anlatı kişileri, eyleyenler, anlatı izlencesi ve öznenin kipliklerinin incelenmesi sıralamasında planlanmıştır. Öznenin kiplikleri yalnızca anlatı başkişisi olan özne için değil, kesitte yer alan diğer eyleyenlerden gönderen ve karşı özne durumundaki anlatı kişilerinin özne konumuna çekilmesiyle bu kişiler için de yapılmıştır. Bu nedenle temel kiplik incelemesi edinç aşamasındaki öznenin kiplikleri üzerindedir. Kesitlerdeki incelemelerin ardından alt kesitlerdeki kişi ve kipliklerin genel anlatı izlencesiyle bağlantıları belirtilmiştir.

\section{ROMANDAKİ KESİTLER}

Roman temel eylemlere, durum ve dönüşümlere göre beş kesite ayrılabilir. Anlatının başından sonuna doğrusal zaman çizgisinde belirlenen kesitler ardı ardına gelmekle birlikte, her kesit kendi içinde tamamlanmayabilir. Bir kesitin sonucu başka bir kesitin içinde değer bulabilir. Kesitlerin bu şekilde birbirleriyle bağlantılı olması romanın yapısı gereği bir durumdur. Bu çalışmada belirlenen kesitlerde ilk ve son kesit dışındaki her kesitin anlatı izlencesi bir bütün olarak değerlendirilmiştir. İlk ve son kesit genel anlatı izlencesinin eyletim ve yaptırım aşamalarını oluşturan kesitlerdir. Aradaki kesitler ise genel anlatı izlencesinin eylem aşamasını belirtirler. Her kesitin anlatı izlencesi içindeki anlatı kişileri kipsel açıdan incelenmiştir. Kesitler ve kesitlerin konuları aşağıdaki gibi belirlenmiştir.

1. Kesit: Ahmet Cemil'in, ünlü bir şair olma hayalleri

2. Kesit: Ahmet Cemil'in, babasının vefatından sonraki çalışma hayatı

3. Kesit: Ahmet Cemil'in kız kardeşinin evliliği

4. Kesit: Ahmet Cemil'in Lamia'ya olan aşkı 
5. Kesit: Ahmet Cemil'in İstanbul'dan ayrılışı

Kesitlerin adlandırmaları özneye göre şekillenmektedir. Bu da, anlatının Ahmet Cemil'in hayatının kesitlerinden oluştuğunu göstermektedir.

\section{Kesit: Ahmet Cemil'in, Ünlü Bir Şair Olma Hayalleri}

Bu kesit Ahmet Cemil'in basın dünyasından kişilerle olan ilişkilerini ve genel olarak Ahmet Cemil'in gelecek hayallerini anlatır. Bu kesitin anlatı izlencesi, anlatının genel anlatı izlencesinin önemli bir parçasını oluşturur.

Anlatı kişileri: Ahmet Cemil, Ali Şekip, Raci, Saip, Sait, Hüseyin Baha, Ahmet Şevki Efendi ve Hüseyin Nazmi'dir.

Eyleyenler:

Özne: Ahmet Cemil

Gönderen: Ahmet Cemil'in şair olup şöhrete kavuşma isteği (kendisi)

Gönderilen: olma/ol(a)mama

Nesne: Şair olma

Yardımc1: Ahmet Şevki, Ali Şekip, Hüseyin Baha, Hüseyin Nazmi

Karşı özne: Raci

Özne: Bu kesitteki olaylar Ahmet Cemil'in etrafında gelişmektedir. Bu nedenle eyleyenözne Ahmet Cemil'dir. Ahmet Cemil mülkiyeden yeni mezun olmuş, basın dünyasına atılan gelecekte ünlü bir şair olmak isteyen bir gençtir.

Bu kesitteki eyleyenler, özne Ahmet Cemil'e göre düzenlenip anlatı izlencesine yerleştirildiğinde aşağıdaki eyleyen şeması oluşur:

(Gönderen) (Nesne) (Gönderilen)

"Şöhret olma isteği" "Şiir yazma" Şair olma/ol(a)mama"

\begin{tabular}{|c|c|c|}
\hline (Yardımci) & (Özne) & (Karşı Özne) \\
\hline “Hüseyin Nazmi & "Ahmet Cemil" & “Raci” \\
\hline \multicolumn{3}{|l|}{ Hüseyin Baha } \\
\hline Ali Şekip & & \\
\hline
\end{tabular}

Ahmet Şevki Efendi"

Şekil1: 1. Kesitin Eyleyen Şeması

Gönderen, anlatı izlencesi açısından özneyi bir eyleme zorlayan eyleyendir. Daha önce de belirtildiği gibi eyleyenler insan olabileceği gibi -özne dışında- insandan başka nesne, değerler ya da soyut şeyler de olabilirler. Bu anlatıda Ahmet Cemil'i harekete geçiren şeyin 
kendi içinden gelen bir istek olduğu görülür. Bu istek şöhret olma isteğidir. Bu isteği şu satırlarda da görülür:

“Henüz yirmi iki yaşında, bütün maneviyeti [ruh hali] yalnız bir ümidin tahakkukuna muntazır [gerçekleşmesini beklemekte] ... Şöhret bulmak, edip olmak, herkesçe tanınmak, bugün o kadar acılıklarına göğüs vermek için hayatını zehirlediği bu edebiyat âleminin bir gün yüksek zirvelerine [doruklarına] çıkmak ve ismini o kadar yükseltmek ki..." (39) ${ }^{1}$

“... şu kitapçı dükkânları, cam kapıların aralarından fark edilen şu kütüphane müdavimleri [gediklileri], bu matbaalar, sabahtan akşama kadar fikir ve sanat hareketlerinin münferit mecrası [tek yolu] olan şu cadde, bir gün olacak ki onun teshiri [etkisi] altına girmiş olacak. Şimdi birkaç eski mektep arkadaşıyla sekiz on kalem erbabından [yazardan] başka, herkesin meçhulü olan bu genç, bugün koltuğunun altında bir iki kitapla bir gölge gibi çıkarken bir gün olacak ki, tesadüfen bir kitapçının dükkânına gözü isabet edecek olursa [rastlarsa]mektepten henüz çıkmış iki genç edebiyat müntesibinin [sevdalısının] birbirine kendisini gösterdiğini fark edecek... Ah! O zaman göğsü nasıl bir iftihar [övünç] havasıyla şişecek!" (s. 40)

Yukarıdaki cümlelerde gönderenin özne içi bir gönderen olduğu görülür. Yani eylemine geçmesi için dışarıdan bir zorlama, öneri, telkin, esin gibi özneyi eyleme geçirici bir etki yoktur, kişi kendini güdüleyerek eylemini gerçekleştirir. Genel olarak içeriden gelen bir istek (bir gönderen), dışarıdan gelen bir zorlama ya da buyurmadan daha fazla etkilidir. İç istekten dolayı gönderen de özne de aynı eyleyendir. Gönderenin arzusu, aynı göndereni özneye dönüştürüp onu eyleme geçirmiştir. Şöhrete ulaşma isteğinin eyletimiyle şiir yazar, bir eser sahibi olmayı ister.

Yardımcı olarak değerlendirilebilecek kişiler; Hüseyin Nazmi, Ali Şekip, Ahmet Şevki Efendi ve Hüseyin Baha'dır. Bu kişilerin özneye farklı açılardan yardımları olur. Ali Şekip, Ahmet Cemil'in çevresindeki bilgili aydın insanlardan biridir:

“Mir'at-i Şuun yazı heyetinin en ziyade malumat [bilgi] sahibidir. Hukuka nispeti [bağlılığı] vardır, çok kitap okumak sayesinde az çok her şeyden anlar, küçük yaşından beri matbuatta çalışmıştır, cihan [dünya] siyasetinin en ehemmiyetten ari [önemsiz] tafsilatı [ayrıntıları] bile ezberindedir. Sanki bir kamus-1 ulum [ansiklopedi] gibi beyninin içinde yapraklar döndükçe malumat tenevvü eder [bilgiler çeşitlenir]" (s. 30).

Bazı kişilerin öznenin eylemini engellememesi de yardımcı olarak değerlendirilmelerine neden olabilir. Örneğin gazete sahibi Hüseyin Baha, Ahmet Cemil için doğrudan olmasa da dolaylı olarak bir yardımcı olarak değerlendirilebilir. Hüseyin Baha'nın

\footnotetext{
${ }^{1}$ Bu bölümdeki alıntılar, Uşaklıgil H. Z. (2011). Mai ve Siyah. İstanbul: Özgür Yayınları, kaynağından alınmıştır. Parantez içinde ilgili yayındaki sayfa numaraları verilmiştir.
} 
düzenlediği yemek daveti Ahmet Cemil'in basın dünyasından kişilerle bir araya gelmesini ve kendini ifade edebilmesini sağlar.

Ahmet Şevki Efendi karşı özne olarak değerlendirilen Raci'ye karşı olumsuz hisleriyle yer alır.

"Matbaada onu kimse sevmez, hele idare memuru - o kendisine Ahmet Şevki

Efendi diyen yuvarlak adam- Raci'den bahsolunsa ateş püskürür; onun kadar mahsuben [hesabına geçirerek] para alan, matbaada kimsenin bulunmadığ 1 zamanlar tesadüf ederse [rastlarsa], gelen ilanların ücretini haczeden [iç eden] bir muharrir [yazar] hiç görmemişti" (s. 29).

Karşı özne hakkında böyle düşünen kişi özneye dolaylı yoldan bir yardımcı sayılabilir. Hüseyin Nazmi, sadece bu kesitte değil anlatının tamamında öznenin en yakın arkadaşı, sürekli yardımcısıdır. Bu kesitte özne, Hüseyin Nazmi'den olumsuz söz eden kişilere karşı onu savunur. Düşünce olarak ortak noktalarının bulunduğu belirtilir. Bu kişilerin varlığı, öznenin eylemini gerçekleştirebilmesi için doğrudan ya da dolaylı olarak yardımcidır.

Karşı özne: İyi bir şair olmak, şöhrete kavuşmak isteyen özne karşısında bilinçli bir engelleyici, karşı özne vardır: Raci. Raci başarılı insanlara tahammül edemeyen bir yapıdadır: "Güya diğerlerinde bir meziyetin teslimi kendisinde bir noksan tevlit edecekmiş [bir eksiklik meydana çıkaracakmış] gibi bir küçük tahsin tebessümünü [beğenme gülümseyişini] bile esirgerdi" (s. 28).

Bu kişi, öznenin nesnesine ulaşmasını engelleyip, aynı nesneye kendisi ulaşmaya çalışır. Ahmet Cemil gibi şair olmak istemektedir. "Raci, o adamlardan biri idi ki dünyaya hiçbir şey olmamaya mahkûm edilerek geldikleri halde her şey olmak isterler. Raci de en ziyade [çok]olamayacağı bir şey olmaya yelteniyordu: Şair..." (s. 27)

Kesit Ahmet Cemil gibi şair olmak isteyen karşı özne Raci'ye göre de değerlendirilebilir. Burada nesne ve özneler arasındaki ilişki kuramsal bölümde sözü edilen ilişkilerden farklıdır. Burada karşı özne ile özne aynı nesne peşinde değillerdir. Aynı eylemi yapmak, ikisi için de ayrı ayrı söz konusu olabilir. Ancak bu anlatıdaki karşıtlık düşünsel bir karşıtlıktır, öznelerin savunucusu oldukları düşüncelerin karşıtlığından kaynaklanan bir durumdur. Eyleyen şeması Raci'ye göre oluşturulduğunda onun eyleyenleri aşağıdaki gibi düzenlenir:

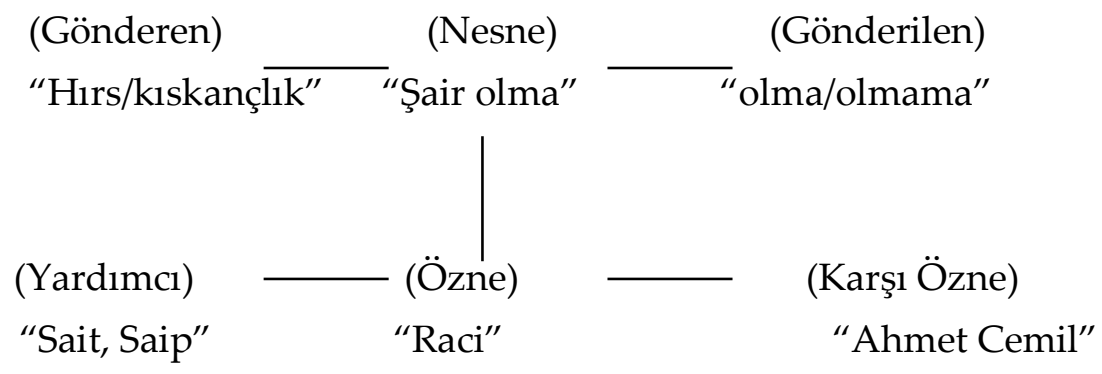

Şekil 2: 1. Kesitin Karşı Özneye Göre Düzenlenmiş Biçimi 
Raci'nin göndereni de bir tür içsel istektir ancak onun isteği başkalarına zarar vermekten çekinmeyen hırs olarak belirlenebilecek bir istektir. Amacını gerçekleştirebilmek için aynı amaca yönelen farklı düşüncedeki kişileri engellemeye çalışarak nesnesine ulaşmayı planlamaktadır.

\section{Öznelerin Kiplikleri}

Özne: Ahmet Cemil, şair olmak ile ilgili tam bir /isteme/ kipliğine sahiptir. Bu konuda kendi isteği çoğalarak bir gönderene de dönüştürmüştür. Bu nesneyle ilgili /bilme/ kipliğine de sahip olduğunu düşünmektedir ve şairlik, şiir, dil hakkında karşı özneye söyledikleri bu bilgiyi diğer eyleyenlere de gösterir:

“Bilseniz, şiirin nasıl bir lisana muhtaç olduğunu bilseniz! Öyle bir lisan ki... Neye teşbih edeyim [benzeteyim] bilmem?.. Mütekellim [konuşan] bir ruh kadar beliğ [güzel] olsun, bütün kederlerimize [sıkıntılarımıza], neşelerimize, düşüncelerimize, o kalbin bin türlü inceliklerine, fikrin bin çeşit derinliklerine, heyecanlara, tehevvürlere [öfkelere] tercüman olsun; bir lisan ki bizimle beraber gurubun mahzun [güneşin batışının üzüntülü] renklerine dalsın, düşünsün ..." (s. 22-23).

Bunları söyleyerek özne, bir bakıma karşı özneden üstün yanlarını, bilgisini, kendi şiir tarzının dile daha fazla anlam sunduğunu kanıtlamaya çalışır. Karşı öznenin kipliklerinden /bilme/ kipliğine bu şekilde müdahale ederek onu /ikna etmek/ için bilgilere başvurur. Birinci kesitteki /bilme/ kipliği, öznede iki biçimde görülür:

/Bilme/: şiiri bilme, sanatsal anlatım özelliklerini bilme, duygularını anlatabilme, yeteneğini bilme, düşüncelerinin farkında olma.

/Bilme/: karşı özneden daha fazla şey bildiğini göstermek.

$\mathrm{Bu}$ iki kiplikten birincisi ilgilenilen alanla ilgili bilgilerin ne olduğunu bilmeyi anlatırken, diğeri bilinenlerin karşı özneyle karşılaştırılmasını anlatır.

Özne, /muktedir olma/ kipliğinde ve /bilme/ kipliğindeki eksiklerinin farkındadır ve bunları tamamlama yönünde hem kendisinin çalışmaları hem de yardımcılarının desteği vardır. Kendisinin çalışmaları, yetiştirim sürecindedir. Yetiştirim süreci, öznedeki eksikliğin (özellikle bilgi ve güç) kısa sürede giderilemeyeceği bir durumda ortaya çıkar. Gönderen ile özne arasındaki kipsel bir ilişkidir. Bu kesitte öznenin, kendisinin göndereni olduğu düşünüldüğünde, yetiştirme sürecinde olduğunu, Fransız şairlerin eserlerini okuyarak /bilme/ kipliğini kazanmaya çalışttğı söylenebilir. /Bilme/ kipliğinin ardından kendini /muktedir/ kabul edecektir. Şair olmak için gerekli güç, bilgi sayesinde elde edilecektir.

Karşı Özne, Raci: Bir karşı özne olarak/isteme/ kipliğine sahiptir. Ancak bu istek, Ahmet Cemil'in isteme kipliğinden farklı olarak hırsa dönüşmüş, zarar vermekten çekinmeyen bir istektir. 
“Raci, o adamlardan biri idi ki dünyaya hiçbir şey olmamaya mahkûm edilerek geldikleri halde her şey olmak isterler. Raci de en ziyade [çok]olamayacağı bir şey olmaya yelteniyordu: Şair..." (s. 27) cümlesindeki "olamayacağı" eyleminde yer alan olumsuz yeterlik kipliği, /muktedir olma/ kipliğine sahip olmadığını gösterir. Kendi eksik bilgisini ve güçsüzlüğünü başkalarının eksikliklerini göz önüne getirerek kapatmaya çalışır, “Bir gün mesela Ahmet Cemil'in bir makalesinde yanlış bir izafet cümlesi [bağlantı cümlesi] bulduğu için bir hafta alay geçer" (s. 29).

/Bilme/ ve /muktedir olma/ kipliklerinin yetersizliğinin farkındadır ama bunu kabul etmez, tam tersi şekilde göstermeye çalışır. Yani var olmayan bir durumu var gibi göstermeye çalışır.

“Pek ziyade kaide-şinaslıkla müftehirdir [kuracılıkla övünür]; Arapça, Acemce [Farsça]pek iyi bilmek iddiasındadır da bir kere Arapça bir ceridenin [gazetenin] üç satırını tercüme edememişti [çevirememişti]. Ceride vazifesi [görevi] muhbirlerin getirdiği havadisi [muhabirlerin getirdiği haberleri] tashihten ibaret kalır. Ne vakit bir makaleciğe falan ihtiyaç görülse, kendisine havale olunmasından [ısmarlanmasından] korkarak, akşam ziyade kaçırdığından [çok içtiğinden] bahisle sersem olduğundan dem vurur [söz eder]" (s. 29).

$\mathrm{Bu}$ durum, Raci için /olmak/-/görünmek/ karşıtlı̆̆ında göstergebilimsel dörtgen üzerinde incelenebilir. (Karşı özne durumunda olduğu için ve görünen durum da karşıt olduğu için olmak eylemi için “bilgisiz” sözcüğü kullanılmıştır.)

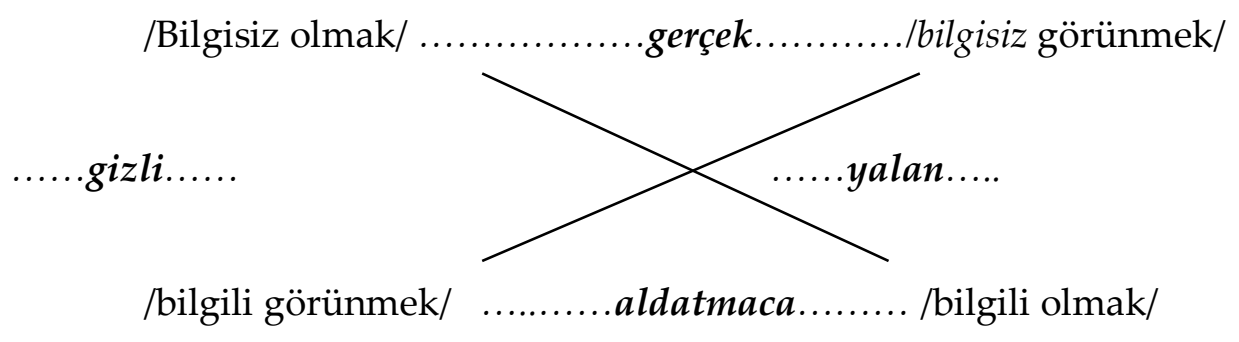

Şekil 3: Olmak Görünmek karşıtlı̆̆ı

Burada görülen /bilgisiz görünmemek/ ve /bilgili görünmek/ durumları karşı öznenin içinde bulunduğu durumları gösterir. Yani karşı özne bir gizlilik ve yalan içindedir.

Karşı özne, öznenin nesnesine ulaşmasını engellemek için onun eksikliklerini bulur, yazdıklarını kötüler, özneyi başarısız göstermeye çalışır. Temel amacı öznenin eylemini engellemek olan karşı öznenin de yardımcıları vardır. Bu anlatıda Sait ve Saip adlı genç şairler, Raci'nin arkadaşıdırlar ve ona yardım ederek, onun tarafında yer alarak Ahmet Cemil'e dolaylı yoldan engelleyici olurlar.

$\mathrm{Bu}$ kesitte öznenin gerçekleştirmek istediği eylem, göndereni ve yardımcıları ve karşı öznesi hakkında bilgiler verilmiş olup eylemin kendisi nesneye yönelmeye henüz başlamamıştır. Kendini yetiştirme sürecindedir. 
Birinci kesitin incelenmesinin ardından anlatı izlencesinde bu kesitin, genel anlatı izlencesinin bir bakıma eyletim aşamasını oluşturduğu söylenebilir. Bu kesit içinde gerçekleşen bir eylem ve bu eylemin sonuçlarına yönelik bir yaptırım söz konusu değildir. $\mathrm{Bu}$ kesitte anlatılanların eylem ve yaptırım aşaması anlatının diğer kesitlerinde belirtilerek genel anlatı izlencesine ulaşılabilir.

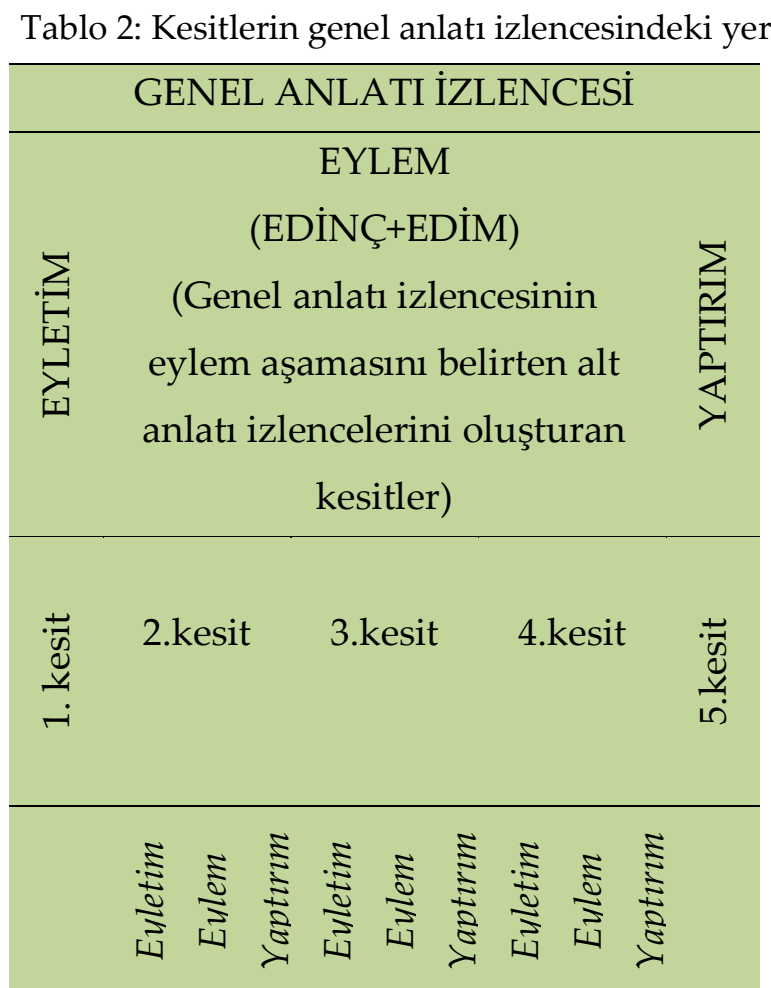

Anlatının ikinci kesitinden itibaren beşinci kesite kadar olan bölüm öznenin eylemini gerçekleştirme çabası içinde olduğu aşamayı belirtir ve bu aşama kendi içinde dört kesite ayrılır. Burada belirtilen her kesit aslında öznenin genel anlatı izlencesindeki eylemi gerçekleştirmesine engel oluşturan sorunlardır. Öznenin bu sorunları çözüp yaptırım aşamasına ulaşması beklenir. Burada belirtilen her sorun kendi içinde ayrı birer anlatı izlencesine de sahiptir. İkinci kesitten itibaren bu izlencelerdeki eyleyenler ve kiplikler incelenecektir. Bu izlencelerin sonuçlarına göre birinci kesitteki eyletim aşamasının eylemi ve yaptırımı gerçekleşecektir.

\section{Kesit: Ahmet Cemil'in, Babasının Vefatından Sonraki Çalışma Hayatı}

Bu kesit, genel anlatı izlencesinde bir dönüşüm yaratan, var olan durumdan yeni bir duruma geçişe neden olan bir kesittir. Ahmet Cemil'in babası vefat etmiştir ve ailesinin sorumluluğu onun üzerindedir. Bir iş bulması, annesini ve kız kardeşini geçindirmesi gerekir.

Anlatı kişileri: Ahmet Cemil, anne, Hüseyin Nazmi, Hüseyin Baha, Ali Şekip

Eyleyenler:

Özne: Ahmet Cemil

Gönderen: Toplumsal Baskı, Maddi Şartlar, Anne 
Gönderilen: Bulma/bulmama

Nesne: İş, para

Yardımcı: Hüseyin Nazmi, Hüseyin Baha, Ali Şekip

Engelleyici: Zaman, dersler

Özne, maddi imkânsızlıklar, annesinin ve toplumun erkek evlat olarak ondan bekledikleri yüzünden para kazanmak için iş aramaya başlar. Bu konuda ona yardımcı olan kişiler vardır, engelleyicisi ise yetmeyen zaman ve diploma sınavına hazırlık sürecidir.

Bu kesitin eyleyen şeması şöyle oluşturulabilir:

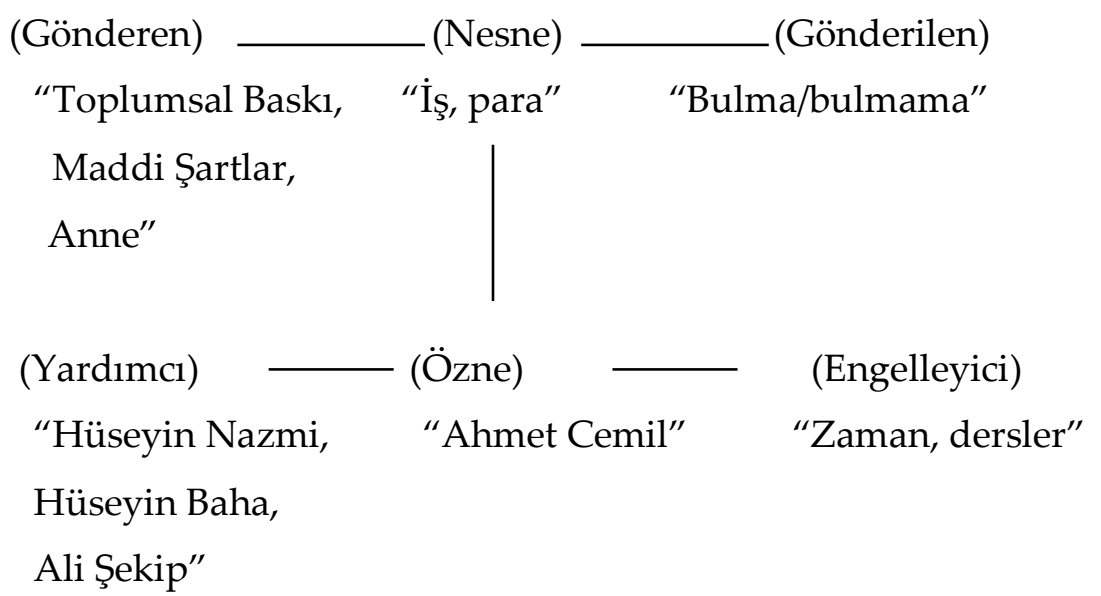

Şekil 4: 2. Kesitin Eyleyen Şeması

Gönderen, özneyi iş bulmaya, para kazanmaya yönlendiren eyleyen toplumsal baskı ve annedir. Anne Sabiha Hanım, çocuklarının mutluluğunu düşünen, ailesini ayakta tutmaya çalışan bir kadındır. "Sabiha Hanım çocuklarının hiçbir halini ve hissini tetkikten [incelemekten] hali kalmayan [uzak durmayan] annelerdendi" (s. 88).

Toplumsal baskı, annenin maddi konuda Ahmet Cemil ile konuşmasından, toplumun anneyi oğluna yönlendirmesinden kaynaklanmaktadır.

Yardımcıları, onu çalışmaya cesaretlendiren Hüseyin Nazmi, Ali Şekip ve Hüseyin Baha'dır. Başlarda küçük küçük ayrı işler yapan Ahmet Cemil, tercüme yaparak yeterli parayı kazanamayacağını anlar. "Bu suretle yaşayabilmek mümkün olamadığına kanaat hasıl etti [kanaat getirdi]. Başka bir şey daha lazım, bir çalışma vesilesi daha icat etmeli, ama ne?..." (s. 83).

Başka işler de aramaya devam eder ve bir dergi basıcısı Mir'at-1 Şuun'da bir iş olduğunu söyler. Birinci kesitte görülen gazetenin sahibi Hüseyin Baha'ya gider ve iş aradığını söyler. Hüseyin Baha yardımcı konumunu Ali Şekip’le paylaşır. Ali Şekip ve Hüseyin Baha onun iş için uygun olduğuna karar verip ona iş verirler.

Engelleyici: Yetmeyen zaman ve okul dersleri öznenin çalışıp para kazanmasına engelleyici eyleyenler olarak değerlendirilebilir. 
"Uykusundan tasarruf etti; küçük odasında herkes yazın sıcağıyla erkence yataklarında uyuduğu bir sırada o kitaplarının üstüne eğilmiş, mütemadiyen [sürekli] işlemekten yorulmaya başlayan zavallı başını iki ellerinin arasına almış, dirseklerinin üzerine dayanmış, artık hariçten [dışarıdan] gelen tesirleri kabul etmek istemeyen fikrine bir senedir mühmel kalan [boşlanan] dersleri sindirmeye çalışırdı." (s. 93-94).

Bu kesitte öznenin nesnesine ulaşmasını engelleyecek bir karşı özne yoktur.

\section{Öznenin kiplikleri:}

Özne: Öznenin temel olarak içinde bulunduğu kiplik /zorunda olma/ kipliğidir. Özne zorunluluğu benimser. Bu zorundalığı belirten pek çok belirtici bulunur. Örneğin annesi, Ahmet Cemil'e “Ne vakit şahadetname [diploma]alacaksın? (67)" diye sorar. Bu soru aslında onun çalışıp para kazanma vaktinin geldiğini ifade eden söylemsel bir belirticidir. Özne zorundalığı gerekliliğe dönüştürebilir. “Demek, şahadetnameyi aldıktan sonra bütün o ümitleri bırakmak, evin ekmeğini aramak için kim bilir nerelere gitmek lazım gelecek?" (s. 73) diyerek kendi durumunu değerlendiren özne, gerekliliğe dönüştürmeye çalıştı̆̆1 bu zorundalık içinde hareket eder. Bu nedenle iki tür /zorunda olma/ kipliği görülür. Biri anne ve toplumdan gelen dış zorundalık, diğeri ise öznenin bu durumu kabul edip kendini harekete geçmek zorunda görmesi. İkinci durum gerekliliğe dönüşmekte olan bir zorundalık haline gelmiştir.

/Bilme/ ve /muktedir olma/ kipliklerinde eksiklikleri olan özne bunları tamamlamaya çalışır, yardımcılara yönelir. Hem yaşadığı sıkıntıyı paylaşmak hem de eksik olan kipliklerini (/bilme/ ve /muktedir olma/) tamamlayabilmek için yardımcı eyleyen Hüseyin Nazmi'ye gider. Hüseyin Nazmi, Ahmet Cemil'in zorunda olduğu bu durumu normalleştirerek onu /ikna eder/.

\footnotetext{
“Evvela bütün çocukluklara, bütün şair düşüncelerine: Siz şimdilik biraz durunuz! demek; hayatı olanca hakikat ve maddiyetiyle [gerçekliğiyle] kabul etmek, madem ki yaşamak için çalışmak gerekiyor, çalışmak. Bana öyle geliyor ki, seni bu kadar perişan eden şey çalışmaktan korku değildir, hayatın henüz bilmediğin bir şeyine biraz vaktinden evvel hasıl ettiğindir [vaktinden önce rastlamandır]" (s. 74)
}

diyen Hüseyin Nazmi Ahmet Cemil'i çalışma konusunda/ikna eder/. Daha sonra Ahmet Cemil'in yapabileceği işleri önerir ve onu /yönlendirir/: "Senin gibi bir adam her iş yapabilir. Sanki ne için mütercimlik etmeyesin [çevirmenlik yapmayasın] hatta hocalık ..." (s. 75) diyerek Ahmet Cemil'e /muktedir olduğunu/ fark ettirmeye çalışır. Ahmet Cemil, Hüseyin Nazmi'ye güvenir. Çünkü onu /bilir/ ve ona /inanır/. Onun fikirlerinin yardımıyla iş aramaya başlar. Tercümeler yapmaya çalışır. Bir müddet sonra bu işe /muktedir olmadığını/ anlar. 
“Ahmet Cemil ayağa kalktı. Odasında gezindi, bir aralık kitabı tekrar aldı, ortasından bir parça okudu, buna verilebilecek tercüme şeklini düşünerek süzüyordu, hiddet etti [sinirlendi], belki diğer eser tercümeye daha müsaittir [uygundur], dedi. Onu da okumak istedi. Artık iyice sıkılmıştı. Muvaffak olamamaktan [başaramamaktan], iktidarını kâfi [gücünü yeterli] görememekten gelen bir sıkıntı..." (s. 78).

Başka tercümelere yönelir. Kitapçılara küçük hikâyeler tercüme eder. Ama bunların yeterli olmayacağını bilir. Tercümeler yaptığı dergi çalışanı Faiz isimli kişi bir bilgi verir:

“Bir gün yine bir makale götürdüğü bir risalenin tabii [yayımcısı] -Faiz Efendi isminde munsıf [insaflı] bir adam ki onun ihtiyaç derdini anlamıştı- dedi ki: Mir'ati Şuun için tefrikalık [dizi yazı halinde] bir hikâyeye lüzum [gerek] varmış, başkası kapmadan imtiyaz sahibine müracaat etseniz...İyi bir adamdır, ihtiraz etmeyin [çekinmeyin]." (s. 84).

$\mathrm{Bu}$ bilgi ve cesaretlendirme ile matbaaya gider, tefrikayı alır. Bunu yaparken Hüseyin Baha'nın matbaasında Ali Şekip'in yardımıyla daha iyi bir iş bulur. Böylece /muktedir olma/ kipliğini tamamlar. Matbaadaki işin yanında dersler vermeye de başlar.

Gönderen: Bu kesitte öznenin göndereni birinci kesitteki gibi tam olarak içsel değildir. Öznenin kabullenmiş olduğu bir /zorunda olma/ kipliği vardır. Gönderen ile özne arasındaki ilişki /ikna etme/, /inanma/ kiplikleri ile ilgilidir. Özne zorundalığına inanmıştır.

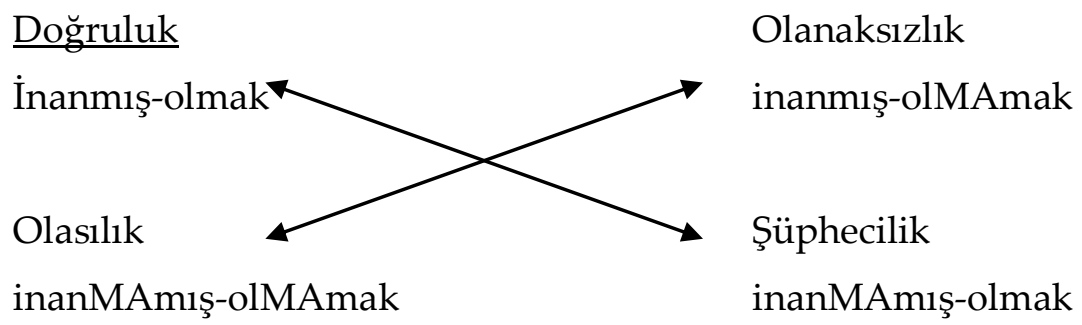

\section{Şekil 5: Öznenin İnanma Kipliği}

/İkna etme/-/inanma/ kipliğinde özne yoğun bir yorumlama süreci geçirmez. İnanılan bir zorundalık vardır. Bu zorundalığın doğruluğu konusunda bilgisi ve inancı tamdır.

Eyleyenler ve kiplikleri belirtilen kesitin anlatı izlencesi aşağıdaki gibi oluşur:

Tablo 3: 2. Kesitin Anlatı İzlencesi ve Öznenin Kiplikleri

\begin{tabular}{|l|l|l|l|}
\hline \multicolumn{1}{|c|}{ Eyletim } & \multicolumn{1}{c|}{ Edinç } & \multicolumn{1}{c|}{ Edim } & \multicolumn{1}{c|}{ Yaptırım } \\
\hline \multicolumn{1}{|c|}{ Gönderen-özne } & \multicolumn{1}{c|}{ Özne-özne } & Özne-nesne & \multicolumn{1}{c|}{ Özne-gönderen } \\
\hline Toplumsal Baskı, & /Zorunda/ & Özne iş & Özne topluma karşı \\
Maddi Şartlar, & Tam /bilmiyor/ & buluyor, & görevini yerine \\
Anne, özneyi & /Muktedir değil/ & para & getirdi. Anne \\
/ikna eder/. & Yardımcılarla kipliği & kazanmaya & tarafından takdirle \\
& tamamlıyor. & başlıyor. & karşllanıyor. \\
\hline
\end{tabular}


Kesit anlatı izlencesine göre kısaca özetlenebilir: /Zorunda olma/ kipliğinin özneyi yönlendirdiği bu kesitte özne yardımcıları sayesinde /bilir/, /muktedir olur/ ve çalışmaya başlar, bir işi vardır, nesneye ulaşmıştır. Bunun sonucunda toplum ve anne tarafından takdirle karşılanır.

\section{Kesit: Ahmet Cemil'in Kız Kardeşinin Evliliği}

Babasının vefatından sonra annesi ve kız kardeşinin sorumluluğunu üzerine alan Ahmet Cemil için kardeşinin evliliği de yerine getirilmesi gereken bir görev niteliğindedir. Ahmet Cemil bu zorundalığı da benimser. Bu kesit Ahmet Cemil ve kardeşi İkbal açısından iki ayrı anlatı izlencesinde incelenebilir. İlk izlence Ahmet Cemil'in özne olduğu izlencedir.

Anlatı kişileri: Ahmet Cemil, Ahmet Şevki Efendi, İkbal, Vehbi Bey, anne, Seher

Eyleyenler:

Özne: Ahmet Cemil

Gönderen: Toplum kuralları/ Ahmet Şevki Efendi

Nesne: İkbal

Gönderilen: evlendirmek/evlendirmemek

Yardımcı: Ahmet Şevki Efendi

Engelleyici: maddi zorluklar

Bu kesitin eyleyen şeması aşağıdaki gibi oluşturabilir:

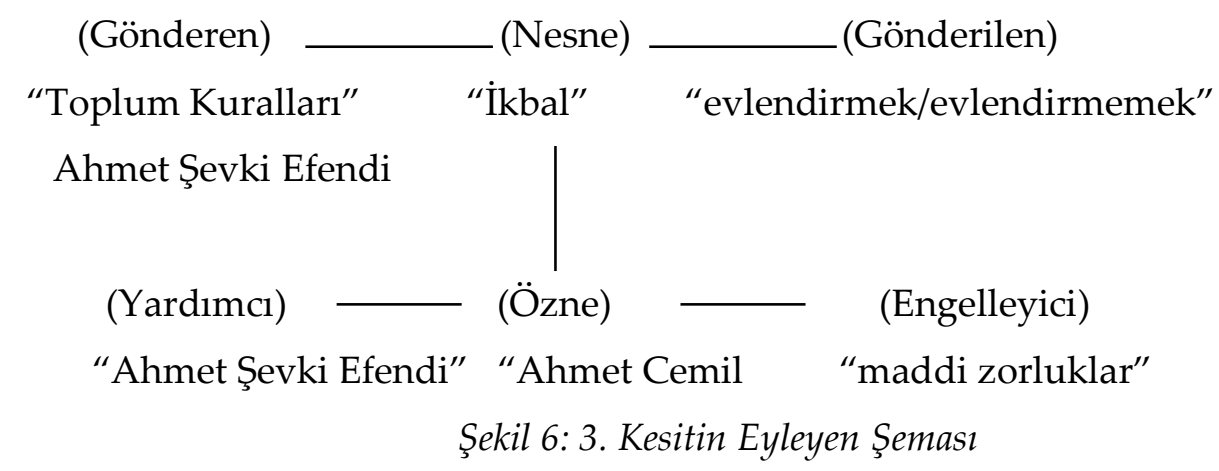

Ahmet Şevki Efendi: Ahmet Cemil'in kız kardeşinin evlenme vaktinin geldiğini Ahmet Şevki Efendi hatırlatır ve kardeşine, matbaanın sahibinin oğlunun talip olduğunu söyler. Kardeşinin evlenmesi konusunda hem bir gönderen hem de bir yardımcıdır. Matbaa sahibinin onunla olan konuşmasını Ahmet Cemil'e aktarır: “Geçen gün bu meseleyi bana açmaktan maksadı tanıdıklarım içinde tavsiyeye değer aileleri tahkik etmek imiş. Benim hemen aklıma sen geldin. Kardeşin artık evlenecek bir yaşa gelmiştir, değil mi?"(s. 180) sözleriyle, özne için bir gönderen konumuna geçmiştir. Ancak öznenin bir engelleyicisi vardır ve bunu gönderenle paylaşır: "Lakin bizim hiçbir şeyimiz yok, dedi, bir kız ne ile evlenir?" (s. 150) Öznenin bu engeline, gönderen, yardımcı olacağını da söyleyerek yardımcı 
eyleyen konumunu da üstlenir: "Orası benim işim. Muvafakat edecek olursan [onay verirsen] ben işi tesviye ederim [ayarlarım]..." (s. 181).

Bu konuşmadan dört kipliğin de olumlu yönde gerçekleşeceğine dair bir izlenim verilmiştir. /Muktedir olma/ kipliğinin yaratacağı engelleyici durum ortadan kalkmıştır. Gönderenin yardımıyla kardeşini evlendirir. Nesneye ulaşmıştır.

Tablo 4: 3. Kesitin Ahmet Cemil Açısından Anlatı İzlencesi

\begin{tabular}{|c|c|c|c|}
\hline Eyletim & Edinç & Edim & Yaptırım \\
\hline Gönderen-özne & Özne-özne & Özne-nesne & Özne-gönderen \\
\hline $\begin{array}{l}\text { Toplumsal } \\
\text { baskı/çevre (Ahmet } \\
\text { Şevki Efendi) } \\
\text { özneyi kardeşini } \\
\text { evlenmesi } \\
\text { konusunda /ikna } \\
\text { eder/. }\end{array}$ & $\begin{array}{l}\text { Özne bu konuda } \\
\text { /muktedir değil/ } \\
\text { ama gönderen } \\
\text { işlevindeki çevre } \\
\text { yardımcı oluyor. }\end{array}$ & $\begin{array}{l}\text { İkbal'in } \\
\text { evliliği } \\
\text { gerçekleşiyor. }\end{array}$ & $\begin{array}{l}\text { Özne topluma } \\
\text { karşı görevini } \\
\text { yerine getirdi. } \\
\text { Çevre tarafından } \\
\text { dışlanmıyor. }\end{array}$ \\
\hline
\end{tabular}

Bu kesitin anlatı izlencesinin aşamaları yukarıda belirtilen şekilde gerçekleşmiştir.

\section{Öznenin kiplikleri}

Özne: Ahmet Şevki Efendi'nin hatırlatması ve ailevi sorumluluğu gereği sonucunda kardeşini evlendirmesi gerektiğini düşünür. Bu eylemi, /zorunda olmak/tan çok gerekliliğe yakın görür. /Gereklilik/, /zorundalık/ ile /istek/ arasında ama isteğe daha yakın bir durumdadır. Bu kipliklerle eyleme geçen özne, maddi zorlukların engelleyici olduğunun farkındadır. Bu konuda /muktedir olmayan/ özne istediği imkânlarda olmasa da nesnesine ulaşır ve İkbal'i, matbaanın sahibinin oğlu ile evlendirir.

Gönderen: Ahmet Şevki Efendi'nin özneyi /ikna edip/ inandırması çok zor olmaz. Öncelikle bunun zamanının geldiğine özneyi /inandırır/, bunun için özneyle ilgili /bilme/ kipliğini kullanır.

"Kardeşin artık evlenecek bir yaşa gelmiştir, değil mi?"

"Ahmet Cemil zihninden hesap ediyordu. İkbal şimdi on yedisine basmıştı. Bu memlekette kızların tam izdivaç zamanı" (s. 180).

/Bilme/ kipliğinin yanında öznenin /isteme/ kipliğini de oluşturmaya çalışır. Bunun için öznenin kipliğine müdahale eder. Özne /muktedir olma/ kipliğinde eksiktir. Gönderen bunu /bilir/, bu kiplik üzerinden özneyi eyleme yöneltmeye çalışır, evlenecek kişinin babasının matbaanın sahibi olduğunu sözlerinin arasına sıkıştırır: “Matbaa da münhasıran [tek başına] herifindir, biliyorsun ya..." (s. 180). 
Gönderen özneyi /ikna etmek/ için bilgiden ve istekten yararlanır. Özneyi bilip tanıdığı için onun hakkında bilgilere sahiptir. Ayrıca öznenin kendisine güvendiği de /bilir/.

\section{İkbal'e Göre İkinci Kesitin Değerlendirilmesi}

$\mathrm{Bu}$ izlencede nesne durumundaki İkbal de bir eylem ve izlence içindedir. Çünkü Ahmet Cemil'in nesnesi ve eylemi, bir başka kişiyi İkbal'i durum değişikliğine götürür. Evlen-dir-mek eyleminde evlenen İkbal, evlendiren Ahmet Cemil"in kendisi ve gönderenidir. Özne durumundaki Ahmet Cemil, bir eylemi yaptırmaya yöneldiği için kendi göndereninin İkbal'in göndereni olmasına da sebep olur. Bu kesitin gerçekleşme aşamasından sonraki bir durumda İkbal ayrı bir özne olarak ele alınabilir. İkinci kesitin sonrası İkbal'e göre değerlendirilebilir.

Özne: İkbal

Gönderen: gelenekler

Nesne: evliliğini sürdürmek

Gönderilen: sürdürmek/bitirmek

Yardımc1: Seher

Engelleyici: Vehbi Bey

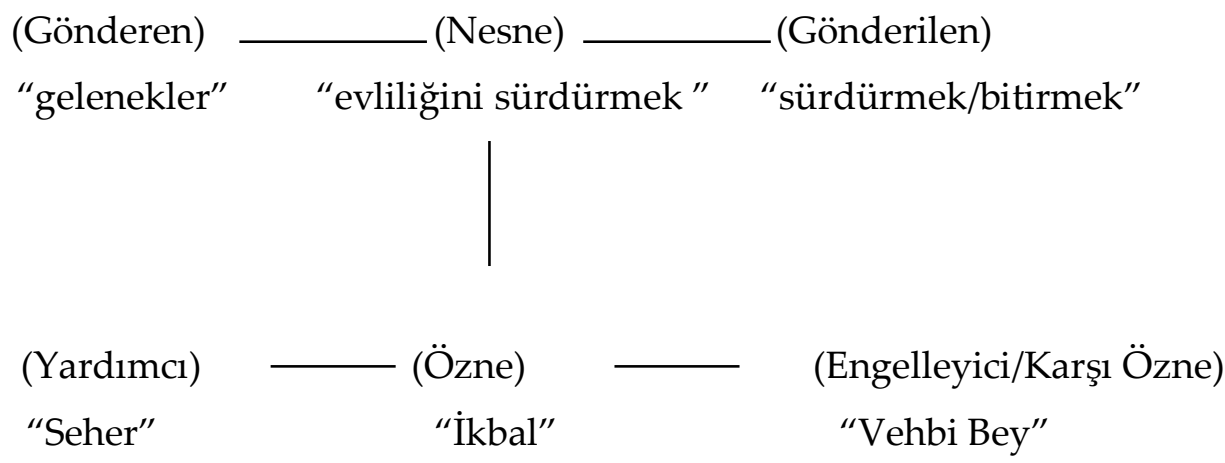

Şekil 7: İkbalin Gözünden ikinci Kesit

İkbal, Ahmet Cemil'in kız kardeşi, nesnesi olan evliliğini sürdürmek için uğraşır. Bu izlencede önce özne ve nesne birliktedir ve özne nesneden ayrı düşmemek için eylem halindedir. Göndereni geleneklerdir, evlendirildiği kişiden ayrılamayacağını düşünür. Evliliğinin kötü gidişine rağmen her şey yolundaymış gibi davranır. Hamileyken hasta olur ve vefat eder.

Vehbi Bey, matbaa sahibinin oğludur, babasının varlığına güvenen kendini beğenmiş bir adam olarak görülür. Babasının vefatın ardından matbaanın başına geçer. İşlerden çok anlamadığı için Ahmet Cemil'i de matbaaya ortak eder.

Bu kesitin anlatı izlencesi aşağıdaki gibi oluşur: 
Tablo 5: 3. Kesitin İkbal Açısından Anlatı İzlencesi

\begin{tabular}{|l|l|l|l|}
\hline \multicolumn{1}{|c|}{ Eyletim } & \multicolumn{1}{|c|}{ Edinç } & \multicolumn{1}{c|}{ Edim } & \multicolumn{1}{c|}{ Yaptırım } \\
\hline \multicolumn{1}{|c|}{ Gönderen-özne } & \multicolumn{1}{|c|}{ Özne-özne } & \multicolumn{1}{c|}{ Özne-nesne } & \multicolumn{1}{c|}{ Özne-gönderen } \\
\hline Öznenin bağlı & Bu aşamada & Özne evliliğini & Özne vefat \\
bulunduğu & öznenin & karşı Öznenin & ettiği için bu \\
gelenekler onu & kipliklerini karşı & gücü & aşama \\
evliliğini & özne etkisiz hale & nedeniyle & gerçekleşmiyor. \\
sürdürmeye & getiriyor. Öznede & sürdüremiyor & \\
zorluyor. Özne de & sadece /zorunda & ama & \\
bunu bir görev gibi & olma/ kipliği & katlanmaya & \\
üstlenip devam & değişmeden & devam ediyor. & \\
ettirmeye çalışıor. & kaliyor. & & \\
\hline
\end{tabular}

İzlencenin son aşaması hastalık ve vefatı nedeniyle gerçekleşmemiştir. Öznenin, evliliğini sürdürme çabası sonuçlanmamıştır. Kesitteki öznelerin kiplikleri aşağıdaki gibidir.

\section{Öznenin Kiplikleri}

Özne: Kendi isteği dışında biriyle evlendirilen İkbal, bu evliliği, -mutsuzluğuna/istememesine/ rağmen sürdürmek /zorundadır/. Bu /zorunda olma/ ilişkisinde gönderen toplumsal koşullar, geleneklerdir. İkbal'e yardımcı eyleyenler annesi ve Seher olarak görülebilir, ancak onlar daha çok yardım etmeyi isteyen kişilerdir, yardımcı eyleyenine tam olarak dönüşemezler. İkbal nesnesi olan evliliğini sürdürmek için uğraşır. Eylemin nedeni ayrı düşmeme isteği değil, ayrı düşmeme zorundalığıdır. Öznenin kiplikleri incelediğinde zorundalık dışında bir kipliğe sahip olmadığı görülür. Yardımcılarının etkin olmayışı diğer kipliklerinin eksik kalmasına neden olur, onu güçsüz ve bilgisiz bırakır. "Hiç öyle mi? Demek İkbal'i kurtarmak için bir şey yapamayacaklar, onu böyle içeride, odaların yalnızlığına iltica ederek [sığınarak] ağlamakta, yeisinden kıvranmakta tek başına bırakacaklardı, öyle mi?"' (s. 289).

/Zorunda olduğu/ bir evliliği yürütmeye çalışan İkbal sonunda hamileyken hasta olur ve dayanamayıp vefat eder. Bu sürece Ahmet Cemil ve annesi yardımcı olarak müdahil olmazlar. “Ahmet Cemil ile annesi, İkbal'in yaşadığ1 gerçeği bir türlü göremezler, iş işten geçince de davranacak gücü kendilerinde bulamazlar" (Finn, 1984:166). İçinde bulundukları kiplik /yapmamak-yapmak/ olarak değerlendirilebilir. Çünkü hiçbir şeye müdahale etmezler.

Karşı özne: Karşı özne Vehbi Bey maddi imkânlarını güç olarak kullanır ve öznenin tek kipliği olan /zorunda olma/ kipliğinin mecbur hale getirdiği evliliği sürdürme çabasına müdahale eder. 
Karşı özne bu süreçte sadece İkbal'e müdahale etmez. İkbal için yardımcı olabilecek Ahmet Cemil'i de baştan engeller. Ahmet Cemil'in eksik olduğu kipliklerin de farkında olan Vehbi Bey, Ahmet Cemil'in /matbaa kurma isteğine/ imkân sunarak bir bakıma onu etkisiz hale getirir. Çünkü Vehbi Bey, bir karşı özne olarak /dönüşlü üst bilme/ kipliğine sahiptir. Vehbi Bey, Ahmet Cemil'in kendisiyle ilgili olarak yeterli bilgiye sahip olmadığını bilmektedir ve bu durumdan yararlanir.

"Ahmet Cemil'in hülya hayatında başlıca ümitlerinden biri bir matbaa sahibi olmak değil mi idi? O halde işte o ümidin bir tahakkuk mukaddimesi [gerçekleşme habercisi] gibi başlayan şu vakaya karşı bir itminan [güven]duymak lazım gelirken ne için makus bir tesir [tam tersi bir etki] duyuyor?" (s. 216).

Olumsuz hislerine rağmen Ahmet Cemil bu teklifi kabul eder. Böylece Ahmet Cemil'in bilgisi ve isteği ile Vehbi Bey'in gücü birleşmiş olur. Bir süre her şey yolunda gider, hatta eniştesine karşı duyduğu olumsuz hisler bile azalır.

“Vehbi Bey, kayınbiraderini para düşüncesinden kurtaracak kadar maharet [beceri] ve tedbir gösteriyordu. Ahmet Cemil şimdi ev masrafından büsbütün elini çekmişti, eniştesiyle beyinlerinde [aralarında] mümkün olabildiği kadar bir samimiyet teessüs ediyor [dostluk kuruluyor], adeta bu adam hakkında ara sira muhabbete benzer hisler duyuyordu." (s. 248).

Daha sonra borçlanan Vehbi Bey, borçlarını Ahmet Cemil'e bırakır ve evlerini haciz altına aldırır. Matbaa hakkında da dava açılacaktır. Bu maddi sorunlar Ahmet Cemil'in daha da güçsüzleşmesine ve bazı gerçekleri (İkbal'in mutsuz evliliği gibi) görememesine neden olur.

\section{Kesit: Ahmet Cemil'in Lamia'ya Olan Aşkı}

Ahmet Cemil, Hüseyin Nazmi'yi tanıdığından beri evlerine gelir giderdi. Bu geliş gidişlerde Hüseyin Nazmi'nin kardeşi Lamia ile de görüşür. O, Lamia'yı tanıdığında Lamia çocukluktan genç kızlığa geçiş çağlarındadır ve Ahmet Cemil için sadece en yakın arkadaşının kız kardeşi olarak vardır. Ahmet Cemil, yaşadığı sıkıntılar ve çalışma saatleri nedeniyle Hüseyin Nazmilere uzun süre gidemez. Sonra bir gün çarşıda Lamia'yı görünce onun yıllardır kafasında oluşturduğu genç kız imgesiyle bire bir örtüştüğünü fark edince, aradığı genç kızın Lamia olduğunu anlar.

“Artık saklamaya ne lüzum var? İşte bütün hüsran [acı] içinde geçen gençlik sevdasının emel zübdesi [arzularının özü], o münevver rüyalarının [parlak rüyalarının] genç kızı, hayatında birinci ve sonuncu olmak üzere seveceği vücut, işte o biraz evvel gülerek, dudaklarını basarak, hafifçe başıyla selamlayarak, "Efendim" diyen Lamia'ydı" (s. 206).

Bu kesitin anlatı kişileri, eyleyenler ve eyleyen şeması aşağıdaki gibidir: Anlatı kişileri: Ahmet Cemil, Lamia 
Eyleyenler:

Özne: Ahmet Cemil

Gönderen: Aşk

Nesne: Lamia

Gönderilen: ulaşmak/ulaşmamak

Yardımc1: kiplikler

Engelleyici: maddi zorluklar

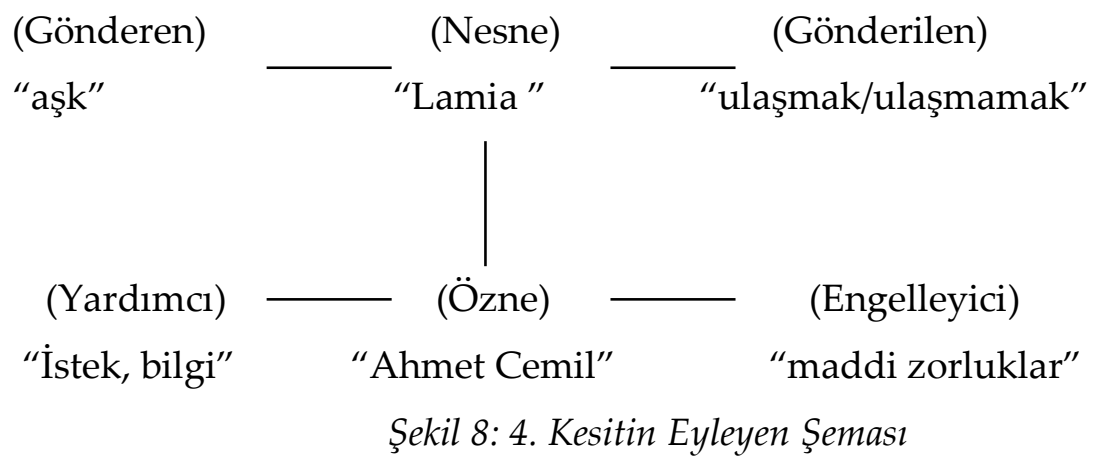

Ahmet Cemil, nesneye ulaşmak /ister/ ama bu isteği için de bir eylemde bulunmaz. Nesneyi bir gün elde edeceğini düşünür, engellerin farkında değildir, başka bir ihtimali mümkün görmez, kendini aşkının heyecanıyla buna /ikna eder/.

"Küçük yaşından beri mahpus [saklı] kalan, tazyik [bastırma duygusu] altında büyüyen sevdası yalnız bir tesadüfle nasıl büyüyüvermiş, aşk istitadına [yeteneğine] isabet eden ufak bir kaza parmağı, o senelerden beri biriken garamını [sevdasını] nasıl taşırmış idi? Bu kadar mağlup, bu kadar esir seveceğine ihtimal vermemiş idi. Zaten hissiyatını zabta [duygularını tutmaya] çalışmıyor, kalbine "Kimi düşünüyorsun? Hazer [Dikkat et]! Hata ediyorsun!" demek istemiyordu" (s. 221).

$\mathrm{Bu}$ cümlelerde kendini engellemeye çalışmıyor ifadesi aslında öznenin bu nesneye ulaşamayacağı /bildiğini/ ancak /bilmek istemediğini/ ve bu durumu yok saydığını belirtir. Öznenin bu kesitteki anlatı izlencesi aşağıdaki gibi oluşur:

Tablo 6: 4. Kesitin Anlatı İzlencesinde Öznenin Kiplikleri

\begin{tabular}{|l|l|l|l|}
\hline \multicolumn{1}{|c|}{ Eyletim } & \multicolumn{1}{c|}{ Edinç } & \multicolumn{1}{c|}{ Edim } & \multicolumn{1}{c|}{ Yaptırım } \\
\hline \multicolumn{1}{|c|}{ Gönderen-özne } & \multicolumn{1}{c|}{ Özne-özne } & \multicolumn{1}{c|}{ Özne-nesne } & \multicolumn{1}{c|}{ Özne-gönderen } \\
\hline Özne içi bir & Özne bunu & Bu aşama & Özne nesneye \\
gönderen/aşk & çok/ister/, & gerçekleşmez. Özne & ulaşamadı̆̆ı için \\
özneyi & nasıl olacağını & bazı şeyler için geç & kendini \\
Lamia'ya & /bilir/ ancak & kaldığını düşünse de & cezalandırır. Ancak \\
ulaşacağına & /muktedirliği & /muktedir olmayışı/ & bu cezalandırma \\
\hline
\end{tabular}




\begin{tabular}{|l|l|l|l|}
\hline /ikna eder/. & $\begin{array}{l}\text { nden/ } \\
\text { şüphelidir. }\end{array}$ & $\begin{array}{l}\text { eylemin olumsuz } \\
\text { sonuçlanmasının } \\
\text { temel sebebidir. }\end{array}$ & $\begin{array}{l}\text { genel anlatı } \\
\text { izlencesinin } \\
\text { yaptırım } \\
\text { aşamasında olur. }\end{array}$ \\
\hline
\end{tabular}

\section{Öznenin Kiplikleri}

Özne:

Bir taraftan gerçeklerin /farkındadır/. /Muktedir olma/ kipliğini tamamlamalı, maddi açıdan Lamia'ya layık bir duruma gelmek /ister/ ve bunun için çok çalışır, iktidar sahibi olma gerekliliğini duyar.

“Lamia'ya: “İşte size memlukiyetini vakfedecek bir el [İşte size köle olacak bir el]!” dediği zaman kendisini onun dest-i izdivacına vasıl olabilecek [onunla evlenmeye layık] bir dereceye yükseltmiş olmak isterdi" (s. 222) ifadesindeki durum gerekliliktir, bir durumun gerçekleşmesi için gereken ön şarttır. Bu aşkın engelleyicisi /muktedir olma/ kipliğinin eksikliğidir. Özne maddi olarak muktedirliğe erişemediği için aşkını Lamia'yla da Hüseyin Nazmi'yle de paylaşmaz. Kendini yeterli görmez. /İsteğin/ ve /bilginin/ olduğu, /muktedirliğin/ eksik olduğu bir anlatı izlencesi vardır.

Özne aynı zamanda yanlış bir bilgi içindedir. Bazı olayları, /olmasını istediği/ gibi yorumlar. Lamia, Ahmet Cemil'in defterinin arkasına "tebrik ederim" yazdığında bu cümleden yoruma dayalı bir bilgi üretir ve kendini bu bilgiye/ikna eder/.

“Bu iki kelime Ahmet Cemil'e Lamia'nın bütün hissiyatının şerhi kadar tafsilat [bütün duygularının açımlaması kadar ayrıntı] ile zengin, aşk zemzemesiyle müterennim [aşk ezgilerini söyler gibi] geldi. O da kendisini seviyor... Bundan emindi; işte yalnız şu iki kelime Lamia'nın ta çocukluğundan beri katre katre birikerek, tazyike [bastırmaya] lüzum görülmeyerek bir aralık taşıveren sevdasının iki açık nişanesi [belirtisi] değil miydi?" (s. 271).

$\mathrm{Bu}$ durumun ardından aşkından ve eserinden başka mutluluğu olamayan Ahmet Cemil, kardeşinin evliliği, hastalığı ile ilgilenmek /zorunda kalır/ ve Hüseyin Nazmi'yle yine uzun süre görüşemez. Bir gün Hüseyin Nazmi, onunla konuşmaya gelir, onu bulamayınca bir not bırakır ve bir haberinin olduğunu söyler. Ahmet Cemil merak içinde kalır ve hemen ona gider. Haber, Hüseyin Nazmi'nin tayininin çıkmasıdır, Avrupa'ya gidecektir ve Lamia da evlenmek üzeredir. Bu haber özneyi yıkar, nesnesine ulaşamamış, ulaşma ümidini de kaybetmiştir. Kendini, edinçlerini sorguladığında /muktedir olmadığını/ tekrar fark eder. “Sonra bütün zavallılığı, fakirliği, mesleksizliği aklına geldi. Lamia’yı ne sıfatla talep edecek [isteyecek]? Ona nasıl bir tasarruf [sahiplik] hakkı gösterebilecek? Lamia kendisinden ne kadar uzak, ne kadar uzaktı!..."(s. 363-364). Daha sonra Lamia'yı gördüğünde yanlış bilgisini, kendi kendisini aldattığını /fark eder/. “Fakat bu öyle bir nazar idi ki hiçbir şey 
ifade etmemekle beraber Ahmet Cemil'e bütün hülyasının bir yalan olduğuna şüphe edilmeyecek bir bedahetle [açıklıkla] şahadet etmişti" (s. 366). Buradaki yanlış bilgi, özneye karşı özneler ya da engelleyiciler tarafından verilmiş bir yanlış bilgi değildir. Öznenin kendisinin yorumlarının sonucu ulaştığı bir bilgidir. Dolayısıyla her zaman tek başına /bilme/ kipliğinin varlığı yeterli değildir. /doğruyu bilme/ de bir ölçüt olabilmektedir. Anlatı izlencesinde öznenin nesneye ulaşamama nedeni temelde /muktedir olma/ kipliğinin yokluğudur. Özne yine de Lamia'nın evlendiği kişiyi engelleyici bir eyleyen gibi değerlendirir.

Bu kesit genel anlatı izlencesinin paralelinde ve belirleyici bir kesittir. Özne için aşkı ve eseri birbirinden ayrı düşünülemez. Aşkının karşılıksız çıkması, özneyi yanıltması, onu eserine de ilgisizleştirir ve özne bir kaçış içine girer, uzaklara gitmek ister.

\section{Kesit: Ahmet Cemil'in İstanbul'dan Ayrılışı (Genel Anlatı İzlencesinin yaptırım} Aşamasi)

Anlatının son kesitinde özne yaptırım aşamasındadır. Yaptırım aşaması öznenin, gönderene gidip, nesne ve eylemiyle ilgili bilgi verdiği aşamadır. Gönderen, özneyi nesneye ulaşma/ulaşmama sonucuna göre ödüllendirir ya da cezalandırır. Yaptırım aşamasında özne eyleminde başarılı olmuşsa genellikle nesnesiyle birlikte gönderene gider. Başarısız olmuşsa gönderen, özneyi eyleme ve nesneye yönelik yargılar ve cezalandırır.

Bu kesit hem genel anlatı izlencesinin hem de yukarıda belirtilen alt kesitlerin yaptırım aşamalarını kapsayan bir kesittir. Gönderen, öznenin kendisi olduğu için başarısızlığının farkındadır ve özne anlatıdaki eylemlerinin sonuçlarına göre bir değerlendirme yapıp kendini cezalandırır. Onuru bu eylemi uygun görür. Bu ceza İstanbul'dan çekip gitmektir.

Anlatı kişileri: Ahmet Cemil, Sabiha Hanım

Eyleyenler:

Özne: Ahmet Cemil

Gönderen: onuru

Nesne: uzak bir yer

Gönderilen: gitmek/gitmemek

Yardımcı: kiplikler

Engelleyici: -

Bu eyleyenlere göre, yaptırım aşamasının eyleyen şeması aşağıdaki gibidir:

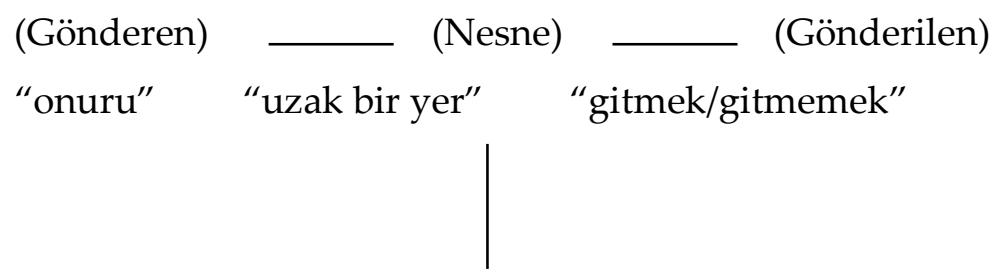




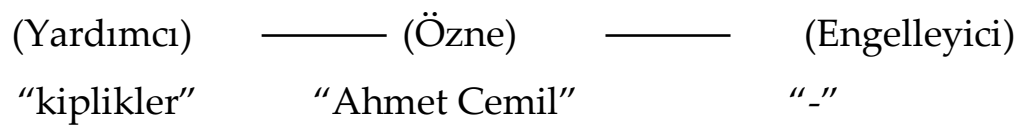

Şekil 9: 5. Kesitin Eyleyen Şeması

İstanbul'dan uzak bir yere gitmeye karar veren öznenin yardımcısı cezalandırmanın sonuçlarına katlanma /zorunluluğu/ olarak değerlendirilebilir. Özne eylemini gerçekleştirir, bir engelleyicisi yoktur. Özne annesiyle birlikte İstanbul'dan vapurla ayrılır ve anlatı burada sonlanır. Eylemin gerçekleştiği bir kesit olarak bu kesit diğer kesitlerdeki eylemlerin istenilen ölçüde tamamlanamamasından kaynaklanan bir cezalandırmadır ve ceza gerçekleşir. Baştaki kesitlere karşıt bir kesit oluşturur.

\section{Öznenin Kiplikleri}

Bu anlatıda özne Ahmet Cemil, gönderen de içsel bir gönderen olduğu için yine Ahmet Cemil'in kendisidir. Bütün anlatı boyunca Ahmet Cemil genel olarak üç konuda kendine vaatlerde bulunmuş, kendini /ikna etmiş/ ve kendini /zorunlu/ hissetmiştir:

- Eserini tamamlayıp ünlü bir şair olmak

- İyi bir iş kurup annesini ve İkbal'i sıkıntısız yaşatmak

- Lamia ile evlenmek

$\mathrm{Bu}$ genel istekler birbiriyle bağlantılıdır. Biri olmadan diğerinin gerçekleşmesi mümkün görünmez. Anlatı sonunda özne kendisiyle baş başa kalır. Başarısızlığını, hayallerini gerçekleştirememesi ve kaybettikleri için kendini yargılar.

“Biraz hayatın maddiyetini [parasal yönünü] düşünmüş, bu toprak parçasının üstünde bir şiir bulutuna sarınarak uçmak için çalışmamış olsaydı bugün bu kadar mağlup olmayacaktı. En küçük sebepleri en büyük hülyalara kâfi addetmiş [yeterli saymış], kendisine sahte esaslar üzerine kurulmuş bir hayat vücuda getirmiş idi. İşte şimdi hakikatin insafsız [acımasız] rüzgârları üzerinden geçtikçe o hülyaları hep birer birer düşürmüş, onu şuracıkta en küçük bir yaşamak arzusundan tam bir mahrumiyet [yoksunluk] içinde bırakmış idi" (s. 381).

$\mathrm{Bu}$ yargılamalarda isteklerine kavuşamama nedenlerini sorgular. Gerçeklerden uzak, hayallerin peşinden koştuğunu düşünür. Ulaşmak istediği nesnelerin gerçekdışı, sahte, kötü olduğunu düşünür. Hayal dünyasında yaşamanın engelleyicisi olduğunun farkına varır. Eseriyle ilgili “Bu eserden nefret ediyor, kırık hayatının intikamını ondan almak istiyordu; kapadı, bu küçük defteri avucunun içinde muzır [zararlı] bir böcek gibi sıkıyordu..." (s. 382) ifadesini kullanır ve sonunda eserini yakar. Lamia'yla ilgili ise, ona ait "tebrik ederim" yazısını yanan defterinde gördüğünde hissettikleri suçlayıcıdır. “Bu sözün aksi vehmi [yankısının kuruntusu] kulaklarının içinde bir zehirli yılanın ıslığı gibi soğuk bir ürperme akıtarak geçiyordu. Ah! Bu yalan! Hayatının en büyük yalanı!..." (s. 384). 
Özne kendisini, değişen düşüncelerini ve kipliklerini eleştirmek istemez. Başarısız oluşunun temelinde /muktedir olma/ kipliğinin eksikliği ve bir türlü eyleme geçememenin bulunduğunun farkında değildir. Finn'in belirttiği gibi “Fiziksel eylem Ahmet Cemil'in yapısında yoktur" (1984:167). Tüm kesitlerde eyleme geçme aşamasında çekimser ve çaresiz kalır. /muktedir olma/ kipliğinin eksikliğinin yanında gerçek bilgi ile düşsel bilginin birbirine karşıması da söz konusudur. Kipliklerden /doğru bilme/ kipliğinin eksik olması, bazı durumlarda /yanlış bilme/ kipliğinin baskın olması eylemlerin olumsuz sonuçlanmasına neden olmuştur. Roman Ahmet Cemil'in düşünce aşamasında kalan gerçekleşmeyen eylemlerinin romanı olarak nitelenebilir. İkbal'in mutsuzluğunu engellemek istemesine rağmen karışmaz:

“İhtilacat ile [çarpıntılar içinde] yumruklarını sıkıyor, odasında geziniyor; bir şeyler yapmak istiyordu. Kardeşini bu bedbahtlıktan kurtarmak için bütün vasıtalara, bütün kuvvetlere malik [sahip] imişçesine yalnız şimdiye kadar lakayt [ilgisiz] kalmış olmasına kızıyordu. Fakat bu ilk hiddet hamlesi geçtikten sonra bir aciz hissi [acizlik duygusu], demin titreyen asabını uyuşturdu. Şimdi bir gevşeklik duyuyor, bu hakikate karşı çaresizlikten azim bir fütür [büyük bir bezginlik] şuraya oturmak, biraz evvel aşkının şiirini okuduğu şu köşede, içerde ağlayan kardeşi için hazin, sakit [üzgün, sessiz] gözyaşlarını akıtmak istedi” (s. 278-279).

Benzer bir durumu Lamia'nın evlendiğini öğrendiğinde de yaşar: "Buna da böyle miskin bir teslimiyet ile [zavallı bir şekilde kabul ederek] mağlup mu olacağım? Bir şeyler yapmayacak mıyım? Bir şeyleri kırıp parçalamayacak mıyım?...Heyhat!! Artık elinde kırılıp parçalanmış bir hayat kalmıştı" (s. 365).

Ahmet Cemil, bütün anlatı izlencesi düşünülerek yalnızca kipliklere göre tanımlandığında, kiplikler açısından kimliği aşağıdaki gibi oluşur:

-/isteme/ konusunda süreksiz,

-eylemleri yapmak için /gücü olmayan/,

-dışarıdan gelen yönlendirmelerle harekete geçen,

-zorunlulukları kolay benimseyip /üstlenen/,

-mücadele ruhundan yoksun bir kişi

$\mathrm{Bu}$ durumların doğal bir sonucu olarak da özne, başaramama duygusunun verdiği üzüntü ile kendini cezalandırır. Tek başına karar aldığı ve uyguladığı tek eylem bu kesitte yer alır. Başkalarının etkisinden kurtulduğunda eylemlerinde sonuca ulaşabileceği söylenebilir. Bu kesitteki gerçekleşen eylem, kendisine verdiği ceza, gitmektir, her şeyi arkasında bırakıp gitmek, sakin ama çok uzak bir yere gitmektir. “Öyle bir yer ki, önünde, ardında, solunda, sağında çöl; yabis [kuru], üryan,medit [uzun] bir çöl olsun..."(s. 386).

Bu cezayı gerçekleştirebileceğine kendini /ikna eder/: “Evet, oraya gideceğim, o sade hayat içinde, ölmüş emellerimin sakit türbesini [sessiz mezarını] orada kuracağım" (s. 389) 
diyerek kesinliği dile getirir. Sonrasında annesiyle birlikte bir vapurla İstanbul'dan ayrılır. $\mathrm{Bu}$ onun genel anlatı izlencesi içinde /yapmayı isteyip/ gerçekleştirdiği tek eylemdir.

\section{SONUÇ}

Başta Ahmet Cemil olmak üzere Mai ve Siyah'ta yer alan anlatı kişilerinin genel anlatı izlencesi içindeki kiplikleri, kesitlerdeki eylemlere göre yukarıda incelenmiştir. Bu inceleme sonucuna göre öznenin kesitlerde edim öncesi kendini sınadığı edinç aşamasında var olan ve olmayan kiplikleri aşağıdaki tabloda özetle sunulmuştur.

Tablo 7: Ahmet Cemil'in Kesitlere Göre Kiplik Durumu

\begin{tabular}{lcccc} 
& /Isteme/ & /Zorunda & /Bilme/ & /Muktedir \\
& & olma/ & olma/ \\
\hline $\begin{array}{l}\text { 1. kesit: Ünlü bir şair olma } \\
\text { hayalleri }\end{array}$ & + & - & + & + \\
\hline 2. kesit: Çalışma hayatı/iş bulma & - & + & - & - \\
\hline 3. kesit: Kız kardeşinin evliliği & - & + & - & - \\
\hline 4. kesit: Lamia'ya olan aşkı & + & - & + & - \\
\hline 5. kesit: İstanbul'dan ayrılışı & - & + & + & + \\
\hline
\end{tabular}

Birinci ve beşinci kesit öznenin kiplikleri açısından tam olduğu aşamalardır. /İsteme/ ve /zorunda olma/ kipliği birlikte yer almadığı için öznede üç kipliğin bulunması edimini başarıyla gerçekleştireceğine yönelik bir varsayım oluşturur. Birinci kesitte özne eyleminde başarıya doğru giderken gerçekleşen babasının ölümü bu eylemden uzaklaşmasına neden olmuştur. Yani öznenin başarıyla giden bir eylemi kesintiye uğramıştır. Beşinci kesitte ise özne tüm kipliklere sahip olduğu için eylemini gerçekleştirebilmiştir. Genel anlatı izlencesinin eylem aşamasını oluşturan üç kesit ise kiplikler açısından eksiktir. Üç kesitte de olmayan kiplik /muktedir olma/ kipliğidir. Özne /istese/ de /zorunda olsa/ da /muktedir olm/a kipliğini tamamlayamadığında, nesneye ya ulaşamamakta ya da yardımcılarının gücüyle ulaşmaya çalışmaktadır ki bu geçici bir muktedirlik oluşturduğundan nesneye ulaşsa bile onu koruma ve devam ettirme konusunda özne yetersiz kalmaktadır.

Günay (2003, s. 112) tarafından edinç ve edim aşaması kipliklerinin karşılaştırıldığ1 tabloda Ahmet Cemil'in kiplikleri anlatı izlencesine göre açıklanabilir.

Tablo 8: Ahmet Cemil'in Edinç Aşaması ve Edim Aşaması Kiplikleri

\begin{tabular}{|l|l|c|}
\hline \multicolumn{2}{|c|}{ Edinç } & Edim \\
\hline Gücülleşme kipliği & $\leftarrow$ Edimselleşme kipliği & $\leftarrow$ Gerçekleşme kipliği \\
\hline
\end{tabular}




\begin{tabular}{|l|l|l|}
\hline $\begin{array}{l}\text { /olmak-istemek/ } \\
\text { /olmak-zorunda olmak/ } \\
\text { /yapmak-istemek/ }\end{array}$ & $\begin{array}{l}\text { lolmasımı-bilmek/ } \\
\text { /olmaya-muktedir olmak/ } \\
\text { /yapmasını-bilmek/ }\end{array}$ & /yapmakl \\
\hline Öznenin ortaya çıkması & Öznapmaya-muktedir olmak/ & \\
\hline
\end{tabular}

Birinci kesitte gücül ve edimsel kipliklere sahip olan özne gerçekleşme aşamasına ulaşamaz. Sonraki üç kesitin kendi alt anlatı izlencelerinde yeti kazanma aşaması eksikliklerle geçer. Öznenin iş bulmadaki /bilgisizliği/, kardeşini evlendirmede ve Lamia'ya olan aşkında /muktedir olmayışı/ edim aşamasındaki gerçekleşme kipliklerine ulaşamamasına neden olur.

Ahmet Cemil'in özne olarak tamamlayamadığı kiplik, belirtildiği gibi /muktedir olma/ kipliğidir. Bu nedenle daha çok boyun eğen, güçsüz bir özne olarak görülür ve başkalarına bağımlı hale gelir. Bu durum /yapmaya muktedir olma/ kipliğinin göstergebilimsel dörtgen üzerindeki adlandırılmasında da görülür:

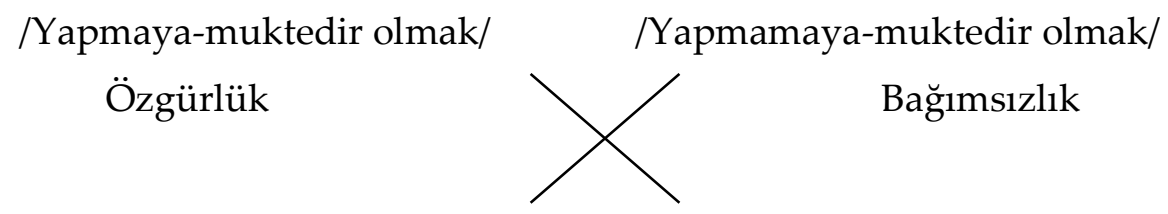

/Yapmamaya-muktedir olmamak/ /Yapmaya-muktedir olmamak/
Boyun eğme
Güçsüzlük

Şekil 10: Yapmak ve Muktedir Olmak Kipliği Arasındaki İlişki

Kesitlerdeki eylemlerde güçsüz ve boyun eğen bir özne olarak belirir. Eserinin yayınlamaya, Lamia'ya aşkını açmaya /muktedir değildir/, bu konularda güçsüzdür. İkbal'in evliliği ve matbaa konusunda ise boyun eğen bir kipliktedir. Evliliğin gerçekleşmemesine /muktedir değildir/, engel olmaz. Kendisine teklif edilen matbaanın başına geçme eylemini kabul etmemeye /muktedir değildir/.

Anlatıda özneye, diğer pek çok bakımdan da olduğu gibi, /muktedir olma/ kipliği açısından karşıt olan anlatı kişisi Hüseyin Nazmi'dir. “Yoksul Ahmet Cemil şiirlerine yöneltilen eleştirilerle sarsılırken, Hüseyin Nazmi'yi hedef alan aynı şiddetteki hücumlar ona dokunmadan geçer" (Yuva, 2011, s. 267). Hüseyin Nazmi, yazmaya, yazdıklarını yayınlamaya /muktedirdi/r. Bu konuda özgürdür. İstemediklerini yapmama konusunda da /yapmamaya muktedirdir/.

Ahmet Cemil /muktedir olma/ kipliğindeki eksikliğine karşın /isteme/ kipliğinde eksiksiz olduğu görülür. Ancak /isteme/ kipliğinin gücülüğü ile /muktedir olmama/ kipliğinin birleşimi Ahmet Cemil'in eylemsizliğinin kiplikle bağlantılı olduğunu gösterir. Özne ister ve heveslidir. Onun arayışlarını her şeye rağmen devamlılığını sağlayan kiplik 
/isteme/ kipliğidir. İstekleri gerçekçi isteklerdir ve özne onları gerçekleştireceğine inanır. Bu inanç konusunda da /isteme/ kipliğinde olduğu kadar süreklidir. /İsteme/ ve /inanma/ kiplikleri süreklilik gösterirken/muktedir olma/ kipliğinde varlık ya da yokluk söz konusudur. Bu durumda devam eden istek ama olmayan güç özneyi yorar, yıpratır. Anlatının sonunda, inancını ve isteğini de yitirdiği için umutsuzluk ve karamsarlık içinde kalır.

Anlatı boyunca Ahmet Cemil güçsüzlügüune karşın, çevresindeki kişiler tarafından her zaman saygı görür ve söyledikleri ilgiyle dinlenir. Özellikle birinci kesitte şiir hakkında söyledikleri çevresindekiler tarafindan dikkatle dinlenir. Bilgisi çok derin olmasa da söylediklerine inancı, inandıklarını savunup söylemesi etkileyici kabul edilir. Burada onun inançlı, ısrarcı, mücadele eden kişiliğinin etkisi vardır. İnançla, daha çok bilgi edinmek, hedeflerine ulaşmak için mücadele eder. Ama bu mücadele daha çok bilişsel düzlemdedir. Bu konuda Ahmet Cemil'in mistik bir yapıda olduğu söylenebilir. "Düşmanlarında bile uyandırdığı saygı, Ahmet Cemil'in kişiliğine ve özellikle söylediklerine peygamber kutsallığı verir. Kişiliğinin mistik özelliğini oluşturan temel nedenlerden biri budur" (Yuva, 2011, s. 269). Bu mistik kişilik, /bilme/ ve /inanma/ kipliklerinin göstergebilimsel dörtgendeki ilişkileri bakımından incelendiğinde, Ahmet Cemil'in bazı şeyler hakkında/bilmeden inanması/ ya da /bilmese de inanması/ bu durumu oluşturan neden olarak görülebilir.

$$
\begin{gathered}
\text { /Bilmek-İnanmak/ } \\
\text { Gerçekçi }
\end{gathered}
$$

/Bilmemek-İnanmak/

Mistik
/Bilmek-İnanmamak/

Dogmatik

/Bilmemek-İnanmamak/

Şüpheci

Şekil 11: Bilmek ve İnanmak Kiplikleri Arasındaki İlişki

Buradaki /bilmemek/, /hiç bilmemek/ olarak değil, /yeteri kadar bilmemek/ olarak değerlendirilebilir. Ahmet Cemil'in bazı konularda derinleşmeye imkânı olmasa da /inancı/ ve /isteği/ son anlara kadar azalmamıştır. Bu tablodaki adlandırmalar Ahmet Cemil'in farklı kesitlerdeki eylemlere bakış açısını adlandırmada da kullanılabilir. Örneğin kız kardeşinin evliliği konusunda şüphecidir. Şairlik konusunda mistiktir. Ancak eylemlerinin başarılı sonuçlanması için ondan beklenen gerçekçiliktir.

Sonuç olarak genel anlatı izlencesinde /isteyen/, /bilen/, /muktedir/ bir özne varken, alt anlatı izlencelerinde farklı eylemler için /zorunda olan/, /bilmeyen/ ve /muktedir olmayan/ durumlarda da görülür. Bu alt anlatı izlencelerindeki kiplikler genel anlatı izlencesinin gelişiminde belirleyici olmaktadırlar. Tamamlanamayan kipliklerin yarattı̆ olumsuz durumlar öznenin eylemlerinin tümüne yansımıştır. 


\section{KAYNAKÇA}

Bertrand, Denis (2000). Précis de Sémiotique Littéraire. Paris: Nathan-Université.

Finn, Robert (1984). Türk Romanı. Çev. Tomris Uyar. İstanbul: Bilgi Yayınları.

Günay, Veli Doğan (2000). “Göstergebilimci Tahsin Yücel” Her Yönüyle Tahsin Yücel, Yayına hazırlayan: Prof. Dr. Mustafa Durak, İstanbul: Multilingual.

Günay Veli. Doğan (2002). Göstergebilim Yazıları. İstanbul: Multilingual.

Günay Veli. Doğan. (2003). “Bilmek ve İstemek Kiplikleri Açısından Özne”. Günümüz Dilbilim Çalışmaları içinde. Yayına Hazırlayanlar: Prof. Dr. Ayşe (Eziler) Kıran, Doç. Dr. Ece Korkut, Dr. Suna Ağıldere. İstanbul: Multilingual Yayınları, s. 43-56.

Günay, Veli Doğan (2004). "Fransız Göstergebiliminde Yeni Açılımlar” Dilbilim Dergisi. Sayı 12. İstanbul: İstanbul Üniversitesi Edebiyat Fakültesi Fransız Dili ve Edebiyatı Anabilim Dalı Dergisi, s. 29-45.

Günay, Veli Doğan (2007). Metin Bilgisi. 3. Baskı. İstanbul: Multilingual.

Kıran Ayşe (2004). "Göstergebilim ve Yazınsal Çözümlemeler" Disiplinlerarası Ortam ve Yöntem Sorunları. Yayına hazırlayan Prof. Dr. Nedret Öztokat. İstanbul: Multilingual, s. 50-61.

Kıran Ayşe (2010). “Çağdaş Bir Düşünme Biçimi Olarak Göstergebilim” Dilbilim Dergisi. Sayı 22. İstanbul: İstanbul Üniversitesi Edebiyat Fakültesi Fransız Dili ve Edebiyatı Anabilim Dalı Dergisi, s. 1-18.

Rifat Mehmet (1998). XX. Yüzyılda Dilbilim ve Göstergebilim Kuramları I. İstanbul: Yapı Kredi.

Uşaklıgil, Halit Ziya (1980). Mai ve Siyah. İstanbul: İnkılap ve Aka.

Yuva, Gül Mete (2011). Modern Türk Edebiyatının Fransız Kaynakları. İstanbul: Yapı Kredi yayınları

Yücel Tahsin (1982). Yazının Sinırları. İstanbul: Adam Yayınları.

Yücel Tahsin (1991). “Göstergebilim” Dilbilim ve Türkçe içinde. Ankara: Dil Derneği Yayınları. Kurtuluş Basımevi, s. 106-110.

Yücel Tahsin (2009). Eleştiri Kuramları. İstanbul: Türkiye İş Bankası Kültür Yayınları. 
TÜRK BILIMMKURGU

\section{EDEBIYATI}

VE ARKETIPLER

DR. VELİ UĞUR

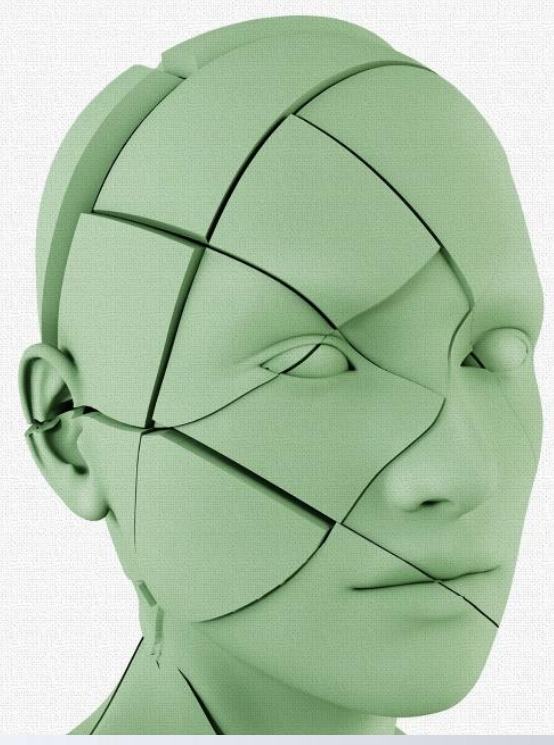

ZEYNÎ EFENDI'NIN ENVÂRÜ'L HÜDÂ'SI ÜZERINE

DIL INCELEMESI

MURTADHA S. NAJMULDEEN

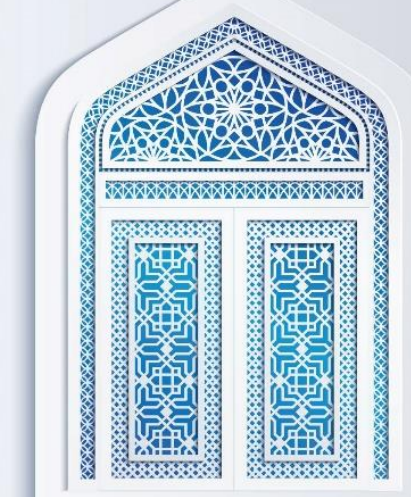

\section{MAKSUT ViěitBBAS}

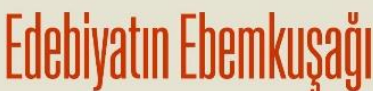

Halit Zijaa Hikâyeceilịinnde Renklerin Dili
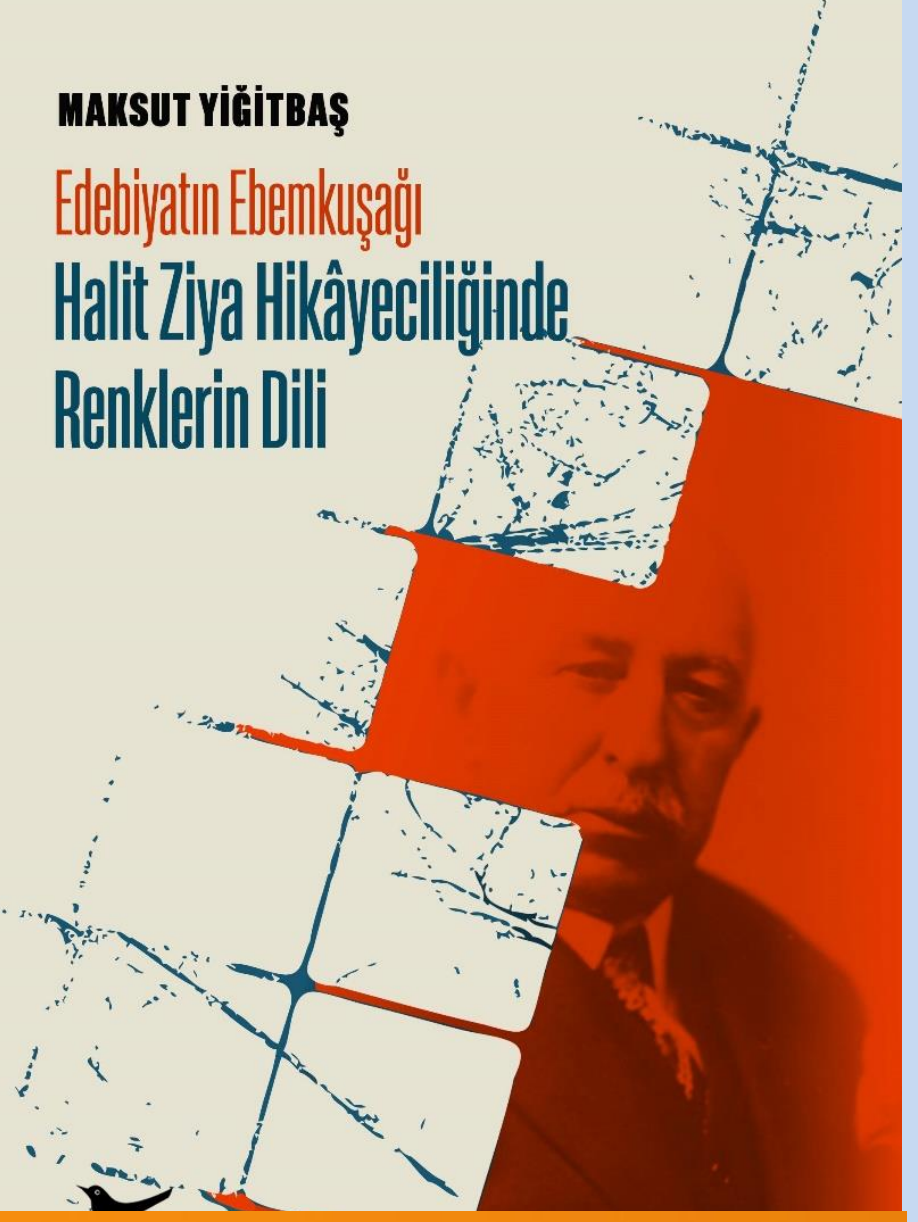

\section{Yazma Sanatı}

Türkçe Doğru ve Etkili Yazma Teknikleri

Prof. Dr. Önder Göçgün

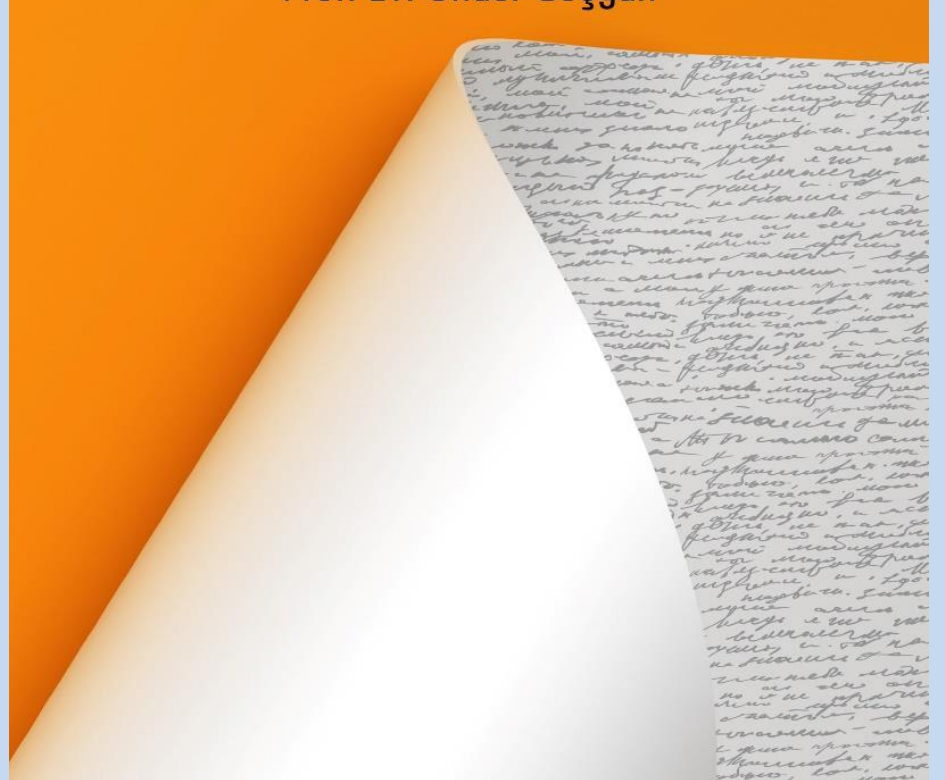

